\title{
Recovery and adaptation after the 2015 Nepal earthquakes: a smallholder household perspective
}

\author{
Kathleen Epstein $^{1}, \underline{\text { Jessica DiCarlo }}^{2}, \underline{\text { Robin Marsh }}^{3}$, Bikash Adhikari $^{4}$, Dinesh Paudel $^{5}, \underline{\text { Isha Ray }}^{6}$ and Inger E. Måren $^{7}$
}

\begin{abstract}
Communities reliant on subsistence and small-scale production are typically more vulnerable than others to disasters such as earthquakes. We study the earthquakes that struck Nepal in the spring of 2015 to investigate their impacts on smallholder communities and the diverse trajectories of recovery at the household and community levels. We focus on the first year following the earthquakes because this is when households were still devastated, yet beginning to recover and adapt. Through survey questionnaires, focus group discussions, open-ended interviews, and observations at public meetings we analyze physical impacts to farming systems and cropping cycles. We investigate respondent reports of loss and recovery through a new social-ecological recovery assessment instrument and find that diversification of livelihoods and access to common resources, alongside robust community institutions, were critical components of coping and recovery. There was widespread damage to subsistence farming infrastructure, which potentially accelerated ongoing transitions to cash crop adoption. We also find that perceptions of recovery varied widely among and within the typical predictors of recovery, such as caste and farm size, in sometimes unexpected ways. Although postdisaster recovery has material and psychosocial dimensions, our work shows that these may not change in the same direction.
\end{abstract}

Key Words: assessment; community resources; coping strategies; disaster; farming systems; Himalaya

\section{INTRODUCTION}

In spring of 2015, Nepal was struck by a string of massive earthquakes and a series of aftershocks, causing approximately 9000 deaths, 23,000 injuries, and the destruction of 600,000 family homes (NPC 2015). Damages amounted to over one-third of the national Gross Domestic Product (GDP). Disasters affect different communities in different ways (White 1945), and rural subsistence-based populations are typically among the most vulnerable (Wisner et al. 2004, Cutter et al. 2006). In this case, mid-hills, smallholder farming communities near the epicenters in Nepal were devastated.

Reducing vulnerability to natural disasters at multiple scales is vital to meeting the broader goals of poverty reduction and sustainable development. The 2030 prediction that " 325 million people [will be] trapped in poverty and exposed to the full range of natural hazards and climate extremes" (UNISDR 2015:2) may explain why so many donors have prioritized risk reduction and resilience building in their strategic planning ${ }^{[1]}$. This focus is not new, however, and can be traced to earlier work recognizing the twin components of vulnerability and asset-building for achieving food security and sustainable rural livelihoods (e.g., Chambers and Conway 1992, Scoones 2009, Ashley and Carney 2017).

Given the pervasiveness of disasters, there is widespread interest in understanding their impacts on agricultural systems broadly, as well as in the capacity of smallholder households to recover and adapt (Scheffer et al. 2001, Folke et al. 2004, Adger et al. 2005, Marín et al. 2014). Recovery in this context refers to a process of "bouncing back" to, or close to, a predisaster state (Klein et al. 2003, Cutter et al. 2008a), whereas adaptation refers to the potential for household, community, or region-wide systems to be transformed into (potentially) stable new states (Folke 2006, Cutter et al. 2008b). We assess diverse aspects of the smallholder farming system to understand the impacts of the 2015 earthquakes, the nature of recovery, and potential for adaptation.

In Nepal, subsistence agriculture accounts for more than twothirds of rural livelihoods and contributes more than $35 \%$ of the national GDP (Ghale 2008, Adhikari 2011). Smallholder farm communities function as tightly coupled human-natural systems where on-farm activities are closely linked with off-farm resources and ecosystem services (Måren et al. 2014). Today, Nepali agricultural systems throughout the mid-hills are transitioning from subsistence and self-reliance to greater market insertion; these changes are being driven by out-migration, economic development, agricultural modernization, and climate change (Pandit et al. 2014, Tulachan 2001). Superimposed on these transitions are environmental shocks and disasters such as landslides, flooding, and earthquakes; all of these can radically alter rural agricultural landscapes and catalyze rapid shifts in farming practices toward broader transformations (Folke et al. 2005).

This study was conducted in Dolakha district, Nepal, in the year following the 2015 earthquakes, a period of recovery and adaptation for affected households and communities. We explored the factors that make smallholder households more or less able to recover from disasters. To understand the impacts and trajectories of recovery after the 2015 earthquakes, we asked the following: (1) What were the specific impacts of the earthquakes on smallholder households? (2) How did smallholder households recover from, and adapt to, these impacts in the immediate aftermath, and over a year? (3) What factors may explain variations in perceptions of loss and recovery among these households? Our work is exploratory and aims to generate, rather than test, hypotheses on postdisaster recovery and adaptation against the backdrop of ongoing transformations.

${ }^{1}$ Department of Earth Sciences, Montana State University, ${ }^{2}$ Department of Geography, University of Colorado Boulder, ${ }^{3}$ Institute for the Study of Societal Issues, University of California, Berkeley, ${ }^{4}$ Institute of Forestry, Tribhuvan University, Pokhara, Nepal, ${ }^{5}$ Department of Sustainable Development, Appalachian State University, ${ }^{6}$ Energy and Resources Group \& Berkeley Water Center, University of California, Berkeley, ${ }^{7}$ Department of Biological Sciences, University of Bergen, Norway 
We addressed our research questions by analyzing postdisaster impacts and adaptation within ongoing agricultural change in mid-hills smallholder communities. Through our mixed methods approach, we sought to show the differentiated damages that the 2015 earthquakes imposed on subsistence farming and mixed subsistence-plus-cash crop systems, and discuss the implications of these differences for farming households. We developed a new self-assessment instrument that captures multiple indicators of recovery to better understand community and household wellbeing. Recovery is an important component of well-being in the aftermath of a disaster, where well-being, following Sen (1985), broadly describes life satisfaction in its material as well as psychosocial dimensions. Accordingly, the self-assessment instrument reveals how households "see" their postearthquake recoveries and includes subjective indicators as well as material indicators such as crop production losses and housing structures repaired. Our analysis focused on the experiences of each and the "fit" between the two. Our work thus acknowledges that although tangible measures of recovery are absolutely critical, psychosocial perceptions, which are often overlooked among smallholder farmers, are also central to well-being.

\section{METHODS}

\section{Study sites}

We conducted our research in Dolakha district, Nepal $\left(27^{\circ} 40^{\prime} 0^{\prime \prime} \mathrm{N}\right.$ $86^{\circ} 2^{\prime} 0^{\prime \prime} \mathrm{E}$ ), population 186,557 (NPC 2015), a mountainous region that was hit hard by the 2015 earthquakes (Fig. 1). The economy is predominantly smallholder agricultural; subsistence farmers grow maize, wheat, rice, and millet on terraced plots. Many farmers maintain livestock including oxen, cows, goats, and chickens, which graze on public or commonly held land. Most maintain small kitchen gardens with fruits, vegetables, and spices. Adjacent forestlands, managed by community forest user groups, provide firewood, timber, fodder, and edible and medicinal plants. Many farmers have adopted cash crops on a part of their lands; the most common are kiwi, vegetables, potato, and cardamom.

Fig. 1. Map of study sites in the Dolakha District of Nepal. Epicenters of the two massive earthquakes 25 April, magnitude 7.8 NW of Kathmandu in Gorkha District and 12 May, magnitude 7.3 NE of Kathmandu in Dolakha District are denoted by $*$.

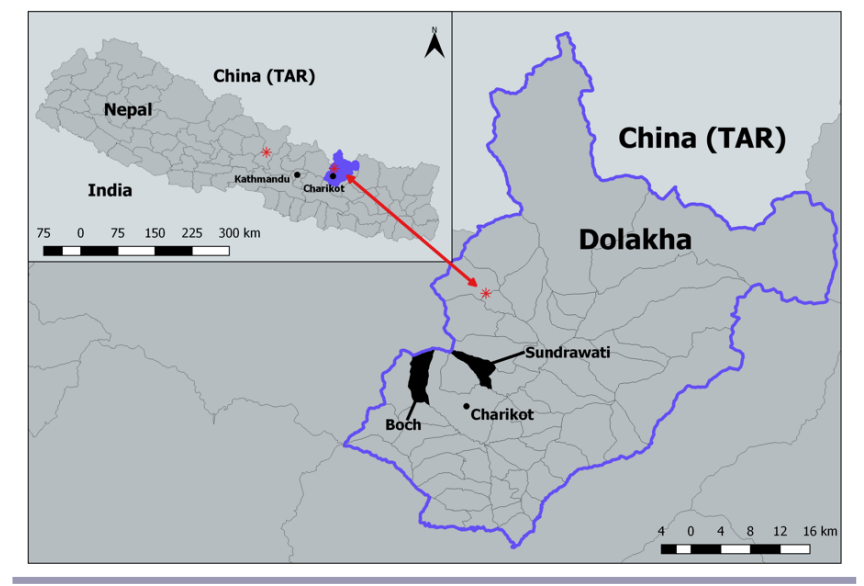

We collected data in the villages of Sundrawati and Boch in Dolakha. These villages are representative of the sociodemographic characteristics, caste range, and agricultural practices of mid-hills smallholder-dominated Nepal (Central Bureau of Statistics 2013; Appendix 1). The mean landholding size was 0.56 hectare in Boch and 0.47 in Sundrawati. We restricted our study to farms between 1500 and 2200 meters above sea level for biophysical and agricultural consistency.

\section{Data collection}

To understand the physical and psychological impacts of the earthquakes on our study communities, we conducted 24 openended interviews with community leaders, farmers, academics, and aid workers, and held five focus group discussions with a range of participants (Appendix 2). We also participated in several public events, including community forestry group meetings, village development committee meetings, and festivals. The interviews focused on pre- and postearthquake experiences at household and individual levels with respect to farming, off-farm livelihoods, coping strategies, adaptation strategies, and access to housing, public services, forest ecosystem services, and relief interventions. Focus group discussions identified communitylevel experiences and acted as a crosscheck on interview results. All interviews were conducted in Nepali and subsequently coded for emergent themes. In addition, we conducted a structured survey to assess earthquake damages among 79 farm households (31 female and 48 male respondents), selected via a random sample, stratified by farm elevation, and based on village development committee census data (2011). The survey (Appendix 3) documented impacts to housing and farm structures, crop production, livestock, water, and seed stocks, as well as community-based institutions and resources.

\section{Recovery assessment}

We developed a comprehensive recovery assessment instrument comprising indicators based on the disaster risk management literature (Cutter et al. 2008a) and social-ecological metrics (Bergamini et al. 2013, O’Connell et al. 2015, Altieri et al. 2015). For disaster-specific scenarios, Cutter et al.'s (2008a) "disaster resilience of place" (DROP) framework unites ecological and social factors with features of the built environment to assess community resilience following natural hazards. Buck and Bailey's (2014) social-ecological indicators develop a landscape framework to elucidate connections among livelihood, agroecosystem, institutional, and ecosystem resilience(s). We built on DROP and Buck and Bailey's work to identify three categories of social-ecological system assessment: farming system and livelihoods, community resources, and household resources. Within these categories, we created a unique set of 10 multiscale indicators and operationalize them into 29 metrics specifically tailored to smallholder farming communities (Table 1).

Each participant compared the status of each indicator across three time periods, (i) immediately before the earthquakes, as a baseline measure; (ii) six months after the earthquakes; and (iii) one year after. All answers for the indicator-based scoring system were self-reported perceptions, coded as -1 if status declined, 0 if it stayed the same, and 1 if it improved. Our purpose was to capture the perceived direction of change and concomitant household perceptions of recovery, alongside more objectively measurable dimensions of material recovery. 
Table 1. List of categories, indicators, and metrics within the "recovery assessment" used to track resilience following natural disasters for small-farm households $(n=79)$. Indicators are derived from the literature and adapted to the Nepali context. We recorded respondents' self-assessment of whether they were doing better, worse, or about the same on each of these metrics at zero to six months after the earthquakes and one year after the earthquakes, compared to before the earthquakes.

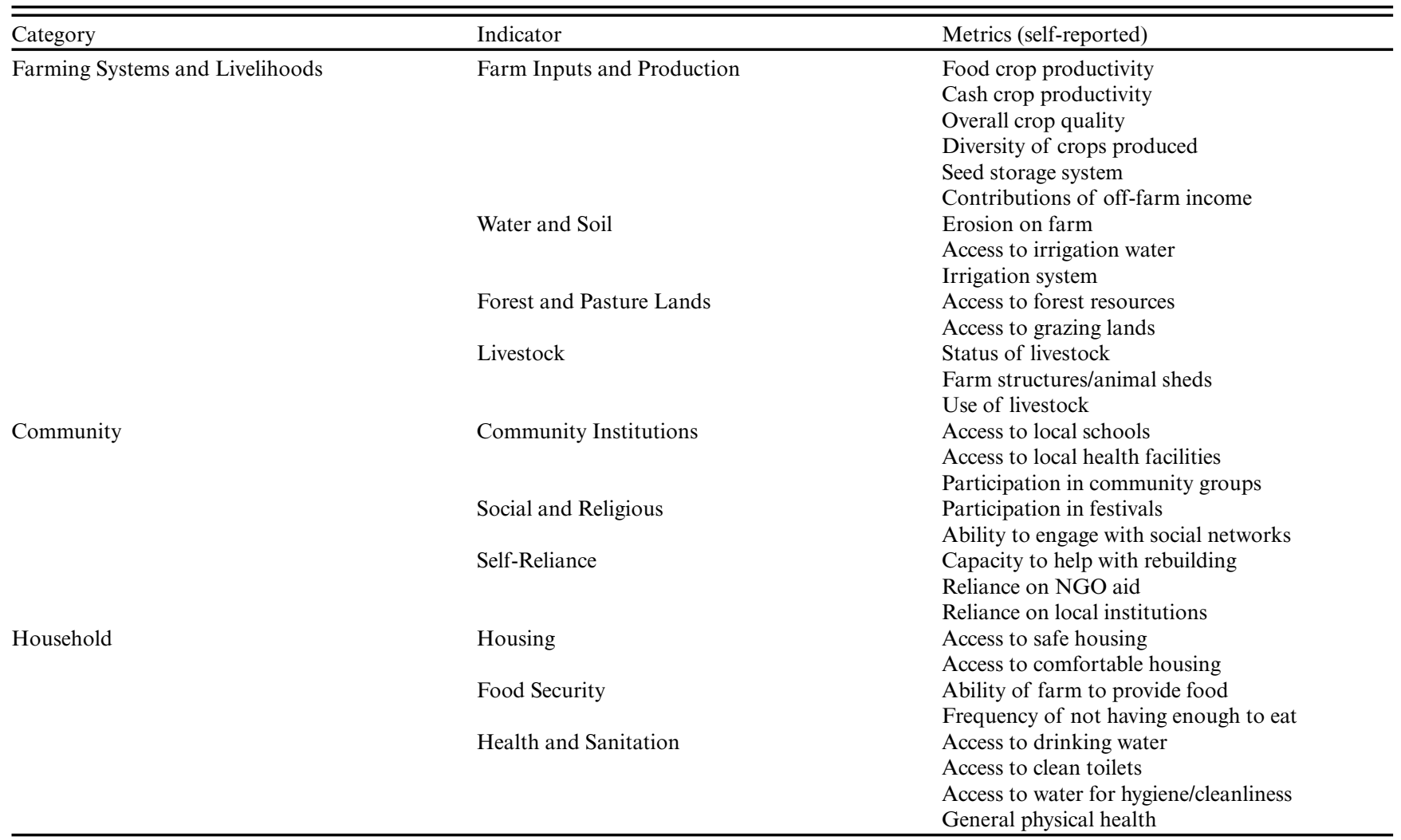

We used these scores as dependent variables to generate descriptive statistics, via simple linear regressions and ANOVA, to show how perceived household-level economic recovery, as well as recovery of general well-being indicators were (or were not) correlated with potential predictors of recovery. The main predictors suggested by the literature are caste, land size, crop diversification, off-farm income (e.g. employment or remittances), and access to community-based common resources (such as forests and grazing land). Finally, we created two visual schematics (Figs. 2 and 3) to show the range of reported recovery pathways to the predisaster "normal" (following Holling 1973), by aggregating individual responses for each time period, for each of the three social-ecological system categories and their respective indicators (Table 1 ).

\section{RESULTS AND DISCUSSION}

Impacts and adaptation strategies

Overall, key inputs to subsistence agriculture, including water, seeds, livestock, and land, suffered the most damage. The earthquakes and associated aftershocks and landslides struck during the maize and millet harvest season, and just as rice paddies were being prepared for planting. Destruction to housing and farm infrastructure was similar across the two communities; reported damage to housing, seed stocks, livestock, and irrigation
Fig. 2. Plot of recovery assessment score trajectories for the four farming system and livelihood indicators (farm inputs and production, livestock, water and soil, and forest and pasture lands; Table 1). Each curve represents an individual respondent; $\mathrm{n}=79$. The direction and magnitude of the trajectory along the X-axis, "0-6 Months after EQ" and "1 Year after EQ," represent an average of responses across the selected indicators. Colors represent respondent's reported caste group: Brahmin and Chettri, Thami and Thamang, and Dalit.

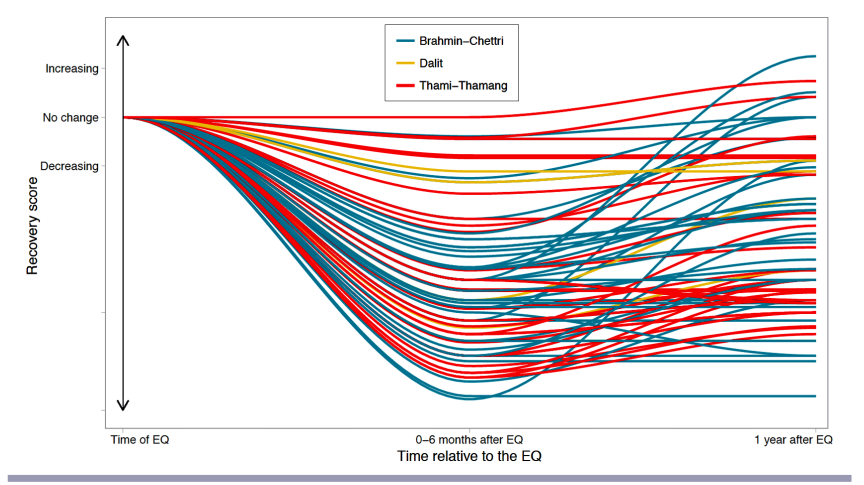


canals was $100 \%, 86 \%, 46 \%$ and $38 \%$, respectively (Table 2 ). In the immediate aftermath of the earthquake, families assisted one another in recovering victims, food, and possessions from collapsed structures. Community-based organizations such as forest user groups and mothers' groups were among the first local responders, distributing timber, firewood, tin, and cash to households on a needs basis.

Fig. 3. Spider diagram of earthquake (EQ) impacts to all 10 adaptation and recovery assessment indicators (Table 1). Scores for individual metrics are averaged across total respondents ( $\mathrm{n}$ $=79$ ). The outer edge represents the self-assessed preearthquake baseline. The closer to the center an indicator falls, the more an indicator declined relative to the pre-earthquake baseline; the closer it is to the outer edge, the more an indicator recovered.

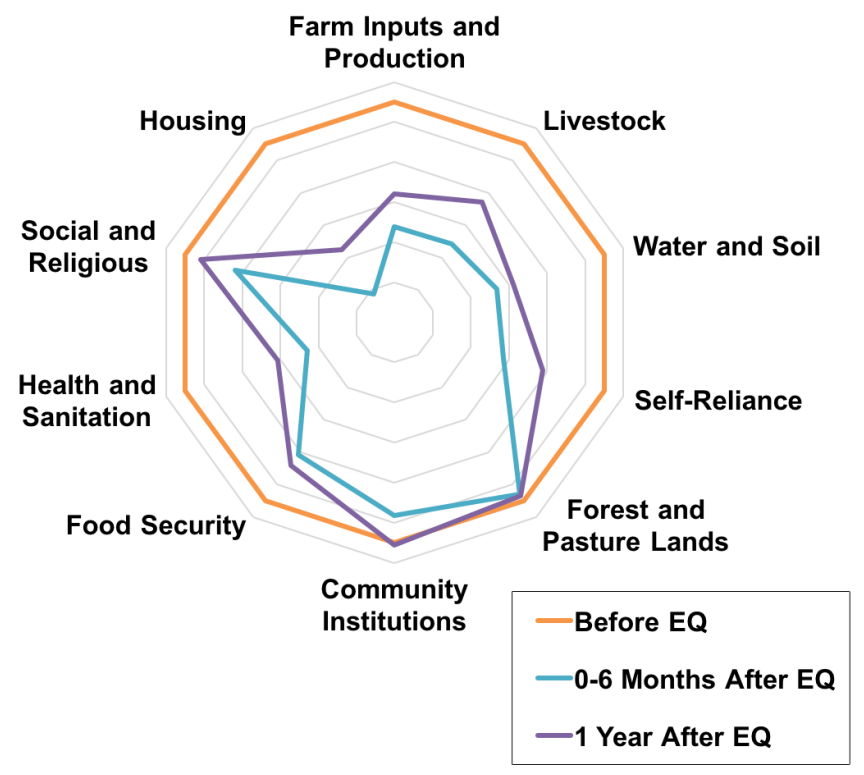

Table 2. Summary of earthquake impacts to farming systems from survey results in both study communities $(n=79)$.

\begin{tabular}{lccc}
\hline \hline Farm system structures and inputs & Sundrawati & Boch & Pooled \\
\hline Housing structures & $100.0 \%$ & $100.0 \%$ & $100.0 \%$ \\
Seed stocks & $84.6 \%$ & $87.5 \%$ & $86.0 \%$ \\
Irrigation canals & $41.0 \%$ & $35.0 \%$ & $38.0 \%$ \\
Livestock loss & $56.4 \%$ & $35.0 \%$ & $45.7 \%$ \\
\hline
\end{tabular}

Damage to fields and terraces impeded subsequent grain cultivation. For wheat, maize, and millet, terraces are essential for good drainage, and for rice, terraces are essential to hold water. Small canal systems were severely damaged, reducing reliable water supply for rice production. Seed stocks of maize, millet, wheat and rice were irretrievable from collapsed houses; lower harvests, by $50 \%$ on average, forced people to eat into seeds kept aside for planting. In the words of the district agriculture development officer: "farming in Dolakha has been set back 10 years."
In the monsoon farming season one year following the earthquake, several farmers started to change their planting regimes. The majority of farmers in both study sites reported large decreases in total acreage planted because of damaged terraces and canals, scarcity and high cost of labor, loss of draught animals, and reduced seed stocks. Projected crop output from the 2016 growing season was consequently well below pre-earthquake levels for both communities, for both cash and subsistence crops (Fig. 4). Just three respondents planted additional acreage after the earthquake; these farmers, all higher caste Brahmin or Chettri, planted cardamom, kiwi, potato, and green vegetables for sale. Our interviews showed that many farmers who experienced severe damage to their subsistence farming systems planned to focus more on labor-saving income-generating cash crops in the future (Table 3).

Fig. 4. Bar chart of changes in crop planting for the 2016 harvest year based on farmer responses. Respondents were questioned on their 2016 planting regimes compared with before the earthquakes. The $\mathrm{X}$-axis shows common crops and the Y-axis shows the number of farmers who planted "less," "the same," or "more" of each crop for the 2016 planting cycle $(\mathrm{n}=79)$.

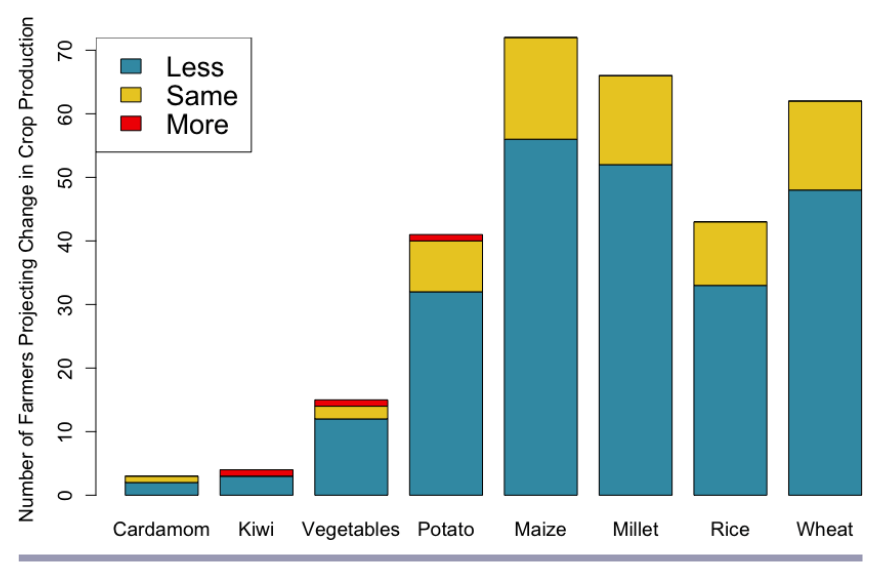

The combined impacts of the disaster and the nature of the aid that followed brought about differentiated adaptation strategies that appear to have hastened ongoing agriculture transitions. For some, it brought greater integration into the labor market and cash economy, for others a contraction of subsistence production and an uncertain future. Our interviews reveal that physical impacts from the earthquakes increased the incentive to integrate more land- and labor-saving cash crops into smallholder systems. Large holes and cracks in the fields made rice or wheat cultivation more difficult or in some cases impossible, and water supplies for cereal crops became unreliable. Cardamom, kiwi, and potatoes remained viable; these crops require purchased inputs, but can be grown on damaged terraces and need light watering compared to grains. Recovery and development interventions further incentivized these transitions through seed donations of cash crops, loans for projects such as greenhouses, and technical training sessions on market-oriented agriculture.

The need for cash during the first year rose sharply. As farm land dedicated to food-grains fell, some families drew on commercial crop sales and off-farm income and remittances, and others 
sought wage opportunities locally. Selling draught animals and other livestock was necessary for some households, in part for cash and in part in response to the reduction in planted area. Access to farm labor fell as priority was given to house reconstruction and relief efforts as government and donor aid came in; the labor that remained for agricultural work became expensive. With the increase of wage labor rates (by up to $50 \%$ ) for postearthquake reconstruction, the poorest households reported increased wage earnings.

Table 3. Individual representative quotations from multiple respondents describing earthquake impacts and responses to farming systems; generated from semistructured and open-ended interviews conducted May-July 2016 in Dolakha District, Nepal.

\begin{tabular}{|c|c|}
\hline $\begin{array}{l}\text { Earthquake } \\
\text { Impact }\end{array}$ & Earthquake Evidence \\
\hline Labor & $\begin{array}{l}\text { Without an ox it's difficult to plow my fields and plant } \\
\text { maize. } \\
\text { I sold my ox after the earthquake because we needed to } \\
\text { sleep in the animal shed and there was no room for } \\
\text { animals. } \\
\text { All of my goats were injured by the earthquake damage. } \\
\text { We were forced to sell them or eat them as meat. } \\
\text { My husband went to get work in Kathmandu to help pay } \\
\text { for our new house. I'm going to start growing kiwis } \\
\text { because they take less work. } \\
\text { I had to leave my khet [irrigated field] fallow. It was too } \\
\text { much work to plant rice. Now I grow potatoes instead. } \\
\text { I used to earn } 500 \text { rupees [US\$5] a day to work in the } \\
\text { farmlands. Now I make almost twice that (Dalit or low- } \\
\text { caste, farmer). }\end{array}$ \\
\hline Water & $\begin{array}{l}\text { Without water to irrigate my farmland, I need a new crop } \\
\text { to plant. My neighbors say cardamom is a good option. } \\
\text { The local springs I use on my farm were damaged after } \\
\text { the earthquake. I want to plant trees near the spring to } \\
\text { protect the water source. I can grow cardamom too. } \\
\text { My irrigation canals were damaged. I have no time to } \\
\text { maintain them. }\end{array}$ \\
\hline Seeds & $\begin{array}{l}\text { Local NGOs are giving away free vegetable seeds, so I } \\
\text { started growing vegetables. } \\
\text { All my maize and rice seeds were destroyed in the } \\
\text { earthquake. } \\
\text { The government has distributed vegetables, kiwi, and } \\
\text { cardamom seeds so I started to grow cash crops. }\end{array}$ \\
\hline $\begin{array}{l}\text { Cash } \\
\text { Income }\end{array}$ & $\begin{array}{l}\text { I can get income quickly from cash crops compared with } \\
\text { subsistence. I need cash to pay for my basic expenses, } \\
\text { which have increased after the earthquake. } \\
\text { I put up a greenhouse this year to grow and sell green } \\
\text { vegetables. It's the easiest way to get money quickly. }\end{array}$ \\
\hline Housing & $\begin{array}{l}\text { The earthquake destroyed our house and we couldn't live } \\
\text { there. Right after the earthquakes, our priority was } \\
\text { finding shelter. }\end{array}$ \\
\hline
\end{tabular}

From a recovery perspective, livelihood diversification is a longstanding strategy of rural communities (Ellis 2000) and may enhance the capacity to manage risk (Barrett et al. 2001) and adapt to change (Marschke and Berkes 2006). At our earthquakestricken sites in Nepal, the majority of respondents remained committed to maintaining some subsistence cropping. At the same time, observed shifts in planting regimes toward commercial crops, coupled with ongoing environmental impacts due to climate change, are likely to have system-wide ramifications.
Other studies have argued, for example, that cash crop-dominated economies often require additional government programs and infrastructure investments that tend to reduce flexibility and increase vulnerability among smallholder communities (Feintrenie et al. 2010).

\section{Self-assessed recovery in agricultural livelihoods}

Our recovery assessment investigated whether households perceived components of their social-ecological system (such as crop production, or access to irrigation water) to be "improving," "staying the same," or "declining" after the earthquakes. Results from the 79 assessment responses show negative impacts across almost all respondents immediately after the earthquakes but substantial variation in the reported degree of recovery within one year (Fig. 2).

Regression and ANOVA analyses of indicators against commonly cited predictors of variation in recovery trajectories, such as livelihood diversity, crop diversity, land size, or caste, did not prove explanatory (Appendix 4). Our extensive interviews and focus group discussions revealed that recovery trajectories and sense of recovery were largely specific to household-level circumstances. All three caste groups show declines in perceived recovery a year out from the shock; the mean scores between the high-caste and the low-caste groups are almost the same, but the spread in recovery scores within the upper two castes (Brahmin-Chettri and Thami-Thamang) is wide (Fig. 2). For example, regarding adaptation and recovery in farming systems, one Dalit family reported little negative impact over six months or one year; the family's land was small ( 0.7 hectare) and had no irrigation, and the farming system, in effect, did not have much to lose or recover from. Their one-year self-assessed trajectory appears stable. A Brahmin family, whose indicators dipped sharply immediately after the earthquake, typically planted crops in both khet (irrigated field) and bari (unirrigated field). The family had much to lose initially, but a rebounded assessment score reflects that they were able to restore planting regimes to near-normal a year after the earthquakes. In contrast, another Brahmin family explained that their viable landholding had plummeted from 10 ropani (approximately $0.5 \mathrm{ha}$ ) to 4 ropani; this family judged themselves as not having recovered at all. Thus similarities or differences in assessment scores between households could embody very different trajectories and material positions, and within-group variation tended to overwhelm across-group variation.

The earthquake initially affected many of the respondents in similar ways. Yet self-assessed recovery trajectories of farming systems were highly differentiated, even among seemingly similar smallholder farmers. The results reveal three general patterns in our qualitative and survey data. First, cash needs for all rose sharply, but access to cash varied widely, including by caste, cultivation of cash crops, access to remittances, and receipt of aid. Relief and recovery measures may have increased access to cash and material goods (through donations of home and farming implements) for very poor farmers, compared to their preearthquake baseline. A few poorer families, for example, felt that their farming systems were about the same or even better a year after the earthquakes. Wage-dependent families benefited from the increased labor demand, and from cash and food aid (one such farmer noted: "now we can give our children rice"). Second, 
households with somewhat larger and more diversified farms felt their losses acutely. This was reflected in sharp dips in their selfassessments. Many were unable in a year to recover to what they saw as a normal material (or social) state. Third, farmers with the quickest improvement trajectories (slope of perceived improvement from the time " $0-6$ Months after EQ" to " 1 Year after EQ"; Fig. 2) had access to broad social networks, both within their villages, in Kathmandu, and in countries abroad, to aid in recovery.

Material estimations and assessments of resilience tend to dominate the postdisaster agricultural literature (Lin 2011, Marín et al. 2014, Castonguay et al. 2016, Seidl et al. 2016), though psychosocial metrics also offer important and nuanced measures of recovery. Although recovery is always a combination of physical and psychological well-being, our findings suggest that we cannot assume that these components will converge (see Carpenter et al. 2005, Cote and Nightingale 2012). It is possible for the most insecure households to feel recovered by experiencing some sense of improvement, at least temporarily, with increased access to aid or wage labor, while other, more asset-endowed and economically secure families remain well below their previous levels of perceived well-being. Future research could fruitfully explore the connections between material and psychosocial dimensions of recovery from natural disasters in smallholder farm communities.

\section{Self-assessed recovery beyond livelihoods}

The recovery assessment included, in addition to farming system and livelihood indicators, aspects of human well-being at the household and community levels within the wider socialecological system. To compare across social-ecological system categories, we aggregated all 79 respondents across all 10 indicators (Table 1). The mean reported recovery rates show declines in the status of all but forest and pasture lands six months after the earthquakes, but substantial recovery in some of them within a year (Fig. 3). Forest and pasture lands were not heavily damaged in the earthquake, so access to fodder collection and grazing lands remained largely intact. Among the householdbased indicators, in addition to the farming system losses, declines persisted in water and sanitation access, housing, and food security. This pattern corroborates the fact that $86 \%$ of households reported reduced access to safe drinking water as a result of damaged springs and wells. Access to and participation in community, social, and religious institutions largely recovered, rebounding to at or near their predisaster levels, a reflection of the strength of existing local institutions. The self-reliance indicator also measured perceived reliance on extra-community assistance, together with perceived ability to assist others. Survey results indicated that, even with overall rebound, Dalits continued to have greater reliance on outside $\mathrm{NGO}$ and government assistance, reflected in their significantly lower self-reliance scores relative to the other castes at the one-year mark (Appendix 4).

In the days following the earthquake, farmers' reliance on and cooperation with neighbors and community-based groups were critical to survival. Local institutions such as community forest groups efficiently and effectively distributed aid before the government and outside NGOs could help. These traditional recovery strategies have coevolved alongside ongoing transitions and environmental shocks such as earthquakes, landslides, and floods (Berkes and Jolly 2001). The role of community resources can be critical, especially for the poorest households for whom common resources may be the entire asset base (Walker and Jodha 1986). In our study, social-ecological indicators of household and farming systems were perceived to have recovered less than those describing community-based indicators for example, access to forest and pasture lands, cultural and spiritual connectedness, and community institutions. Within one year of the disaster, these resources either returned to, or maintained, some level of "normality" (Fig. 3). This concurs with studies that point to the positive link between resilience and religious and cultural practice (Allison 2016), and how strong social networks and robust community structures and institutions are the hallmarks of resilient systems (Folke et al. 2005, Walker et al. 2006).

\section{Impact and transition pathways in smallholder communities in the Himalayas}

These findings are important for highlighting the potential for disasters to hasten ongoing transitions; understanding the significance of, and contradictions in, self-assessed recovery of smallholder households; and generating hypotheses for longer term research on postdisaster recovery and adaptation among such farmers. Based on our case study, we present a schematic to show how the 2015 earthquakes intersected with the ongoing agricultural transitions in these Himalayan smallholder communities (Fig. 5). Focusing on recovery and adaptation within the first year of the shock allowed us to study the strategies of smallholder households when they were most vulnerable, and potentially looking ahead to a more cash-dependent, and possibly more uncertain, livelihood regime. The schematic illustrates how the earthquake affected the availability of subsistence farming inputs, and the specific land and labor requirements of grain crops versus cash crops. Together these changes can reorient the decision pathways for smallholder farming communities. For example, without adequate access to livestock, farmers are labor constrained, which, in our study sites, incentivized the adoption of labor-saving cash crops or other livelihood diversification strategies. The schematic was inductively built up from our specific observations and analysis; it identifies key inputs and their impact on subsistence versus cash-crop dominated farming practices. However, the overall structure of the schematic, with its relational ties between and among inputs and outputs, is hypothesis generating; the direction and weight of specific relationships can and should be tested for other smallholder mountain geographies. Overall, the schematic demonstrates how environmental shocks can act on feedbacks between socialecological system components and push the systems to an alternate state (see Folke et al. 2004, Walker et al. 2006).

Our study had several limitations that moderate our findings and discussion. First, our small sample left us underpowered to detect any changes pre- and postearthquake with statistical significance. In addition, the social and ecological indicators we chose for the recovery assessment are inherently interdependent, and therefore the various components are better seen as a system rather than as discrete and individually explanatory factors. Second, our sampling design aimed to capture loss and recovery in the shortterm aftermath of the earthquakes at a point in time when alleviation of suffering is most critical. Within one year of the earthquake the new crops had not yet gone into the ground; we therefore report on what households were planning to plant as 
Fig. 5. Schematic showing relationships between inputs, outputs, and the direction of impacts among those in subsistence and cash crop production in mid-montane Nepal. Solid arrows represent potentially positive feedbacks; dotted arrows represent potentially negative feedbacks. For example, increased access to forest resources enables more livestock because fodder is plentiful; it also implies lower need for cash because some inputs do not have to be purchased. The overall structure of the framework demonstrates pathways through which inputs to the Nepali farm system support the subsistence practices over the adoption of cash crops, or vice versa. The directions of the arrows are specific to our case.

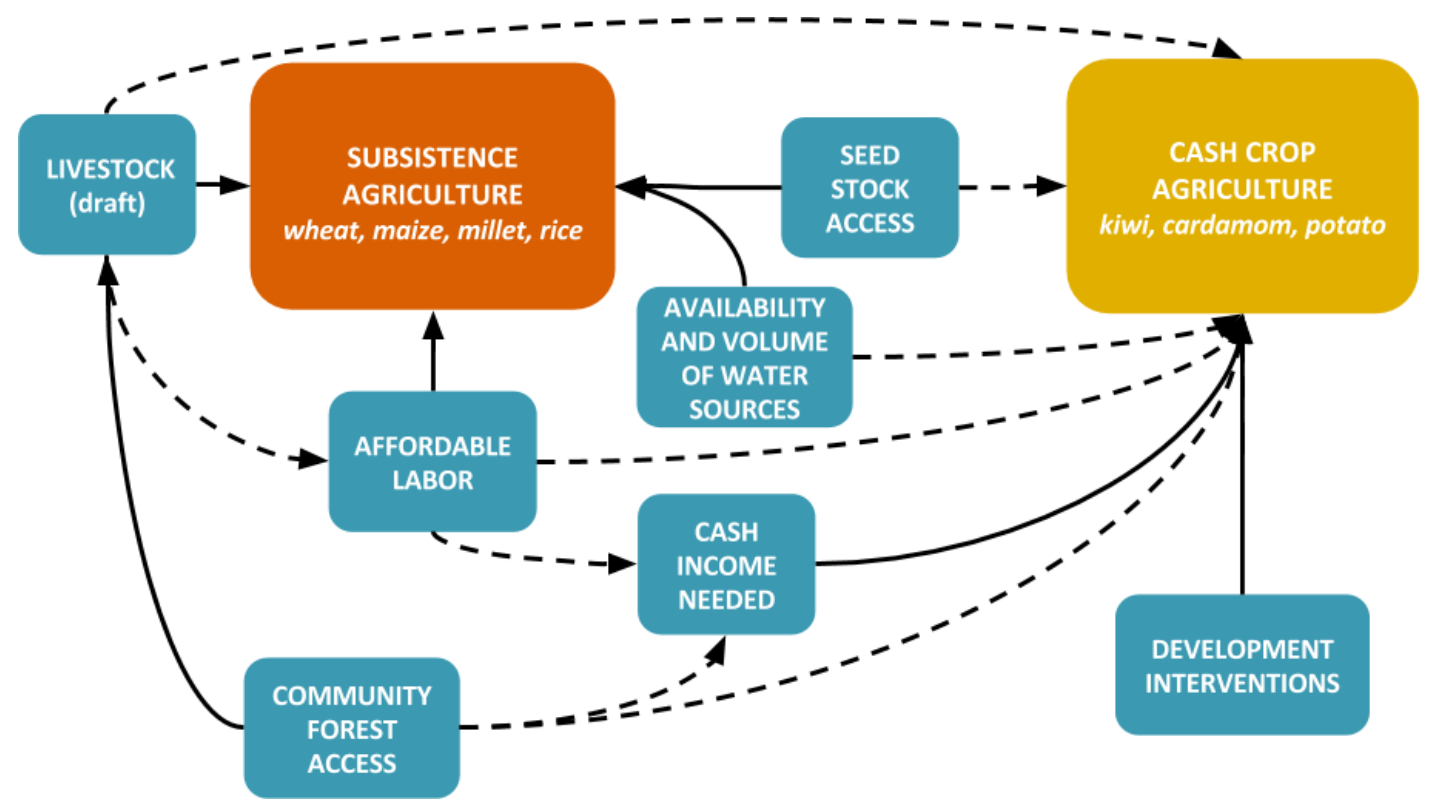

compared to what they had planted before. We cannot extrapolate our findings on perceptions of recovery and adaptation strategies beyond this short term with any degree of certainty. In particular, our hypothesis that the earthquakes have accelerated the transition to cash crops in Dolakha, for some farmers, will require additional verification. Finally, it was clear that all respondents, especially the very poor, benefited from government and donor aid, though some of the aid was not equitably distributed. We were unable to gather a detailed account of how much aid came in, at what times, and from which specific sources; therefore, our discussion of the role that aid played in perceived recovery among the poor is more inference than evidence-based.

\section{CONCLUSION}

Natural disasters are pervasive and affect human populations dramatically but asymmetrically. We investigated how mid-hills smallholder households and communities in Dolakha district, Nepal, adapted to the severe impacts of the 2015 earthquakes on their assets, livelihoods, and sense of well-being. The earthquakes interrupted the tightly knit agricultural cycles of smallholder farmers; breaks in these cycles caused subsistence crop farming to contract sharply as households coped with damaged farm structures and inputs, and prioritized the immediate need for cash. An ongoing move away from self-provisioning to a greater engagement with the cash economy appeared to have been hastened in the study communities.

Even within these broadly similar smallholder communities, capacities to recover, and to feel recovered, were highly differentiated one year after the earthquakes hit. Some of the poorest families felt closer to their preshock "normality" because a small amount of aid and increased wage rates were significant benefits to them, whereas some better-off households still felt shattered. These findings suggest that psychosocial elements uncover perceived levels of recovery that may or may not reflect tangible material security. Concurrently, we find that access to community-based physical, social, and cultural resources played a significant role in households' capacity to adapt and recover.

Across the global south, smallholder farming communities are undergoing transformation in response to the pressures of economic globalization and migration. At the same time, these communities are among the most vulnerable to environmental shocks and disaster events. Given these realities, our research suggests that intervention priority be given to supporting endogenous mutual support groups and community-based institutions that are effective as first responders, particularly for very small and poor farm households. These institutions provided critical support in the immediate aftermath of the Nepali earthquakes, well before governments and donors made their presence felt. However, large-scale events like these earthquakes require a multiscalar and sustained, long-term response (Adger et al. 2005). Current government and international agency strategies to reduce vulnerability and risk would benefit from research-based evidence on communities undergoing postdisaster transitions. We present our assessment instrument as one option for harnessing recall data and psychosocial perceptions toward a better understanding of postdisaster change. We hope that the 
hypotheses generated through this work (shown visually in Fig. 5) will motivate future research agendas on the relationships and feedbacks between key inputs to smallholder farming systems, and the specific transition pathways that are generated by systemwide perturbations. This type of future work will support more precise recommendations for disaster-related policies and relief and recovery measures.

${ }^{[1]}$ Examples include the Rockefeller Foundation, United States Agency for International Development (USAID), The Organisation for Economic Co-operation and Development (OECD), European Union, and Department for International Development (DFID).

Responses to this article can be read online at: http://www.ecologyandsociety.org/issues/responses. php/9909

\section{Acknowledgments:}

We are indebted to the residents of Sundrawati and Boch in Dolakha District for spending time with the field research team and participating in this study. We thank collaborators at ForestAction Nepal: Govinda Paudel, Naya Sharma Paudel, and Dil Bahadur Khatri, for their assistance in field work and initial data preparation. We thank Elizabeth Allison, Cheryl Colopy, John Harte, Philippe LeBillon, and Jeff Romm for their valuable comments and feedback. Michael MacDonald constructed several diagrams and figures including the study sitemap and the plots of recovery assessment scores. Funding for field research was provided by the American Alpine Club and the Peder Sather Fellowship, a joint collaborative of the University of California, Berkeley and the University of Bergen. Funding for writing and publishing was provided by the University of California, Social Science Matrix Research Initiative.

\section{LITERATURE CITED}

Adger, N. A., N. W. Arnell, and E. L. Tompkins. 2005. Successful adaptation to climate change across scales. Global Environmental Scales (15):77-86.

Adhikari, B. M. 2011. Economic survey fiscal year 2010/11. Ministry of Finance in the Government of Nepal, Kathmandu, Nepal.

Allison, E. 2016. Cultivating resilience for addressing ecological change. Embrace of the Earth 2016. 8. [online] URL: https:// digitalcommons.ciis.edu/embraceoftheearth2016/8

Altieri, M., C. I. Nicholls-Estrada, A. Henao-Salazar, A. C. Galvis-Martínez, and P. Rogé. 2015. Didactic toolkit for assessment of resilient farming systems. Third World Network, Penang, Malaysia, Sociedad Científica Latinoamericana de Agroecología (SOCLA), Berkeley, California, USA, and REDAGRES, Berkeley, California, USA.

Ashley, C., and D. Carney. 2017. Sustainable livelihoods: lessons from early experience. Department for International Development, London, UK.
Barrett, C. B., T. Reardon, and P. Webb. 2001. Nonfarm income diversification and household livelihood strategies in rural Africa: concepts, dynamics, and policy implications. Food Policy 26:315-331. http://dx.doi.org/10.1016/S0306-9192(01)00014-8

Bergamini, N., R. Blasiak, P. Eyzaguirre, K. Ichikawa, D. Mijatovic, F. Nakao, and S. M. Subramanian. 2013. Indicators of resilience in socio-ecological production landscapes (SEPLS). UNU-IAS Policy Report United Nations University Institute of Advanced Studies, Tokyo, Japan.

Berkes, F., and D. Jolly. 2001. Adapting to climate change: socialecological resilience in a Canadian western Arctic community. Conservation Ecology 5(2):18. http://dx.doi.org/10.5751/ES-00342-050218

Buck, L. E., and I. D. Bailey. 2014. Managing for resilience: framing an integrated landscape approach for overcoming chronic food insecurity. EcoAgriculture Partners on behalf of the Landscapes for People, Food and Nature Initiative, Washington, D.C., USA.

Carpenter, S. R., F. Westley, and M. G. Turner. 2005. Surrogates for resilience of social-ecological systems. Ecosystems 8 (8):941-944. http://dx.doi.org/10.1007/s10021-005-0170-y

Castonguay, A. C., B. Burkhard, F. Müller, F. G. Horgan, and J. Settele. 2016. Resilience and adaptability of rice terrace socialecological systems: a case study of a local community's perception in Banaue, Philippines. Ecology and Society 21(2):15. http://dx. doi.org/10.5751/ES-08348-210215

Central Bureau of Statistics. 2013. Dolakha: national sample census of agriculture, Nepal. National Planning Commission Secretariat, Government of Nepal, Kathmandu, Nepal.

Chambers, R., and G. R. Conway. 1992. Sustainable rural livelihoods: practical concepts for the 21st century. Discussion Paper 296. Institute of Development Studies, Brighton, UK.

Cote, M., and A. J. Nightingale. 2012. Resilience thinking meets social theory: situating social change in socio-ecological systems (SES) research. Progress in Human Geography 36(4):475-489. http://dx.doi.org/10.1177/0309132511425708

Cutter, S. L., L. Barnes, M. Berry, C. Burton, E. Evans, E. Tate, and J. Webb. 2008a. A place-based model for understanding community resilience to natural disasters. Global Environmental Change 18(4):598-606. http://dx.doi.org/10.1016/j.gloenvcha.2008.07.013

Cutter, S. L., L. Barnes, M. Berry, C. Burton, E. Evans, E. Tate, and J. Webb. 2008b. Community and regional resilience: perspectives from hazards, disasters, and emergency management. Geography 1(7):2301-2306.

Cutter, S. L., B. J. Boruff, and W. L. Shirley. 2006. Social vulnerability to environmental hazards. Pages $115-133$ in S. L. Cutter, editor. Hazards vulnerability and environmental justice. Routledge, London, UK.

Ellis, F. 2000. The determinants of rural livelihood diversification in developing countries. Journal of Agricultural Economics 51 (2):289-302. http://dx.doi.org/10.1111/j.1477-9552.2000.tb01229. $\underline{x}$

Feintrenie, L., S. Schwarze, and P. Levang. 2010. Are local people conservationists? Analysis of transition dynamics from 
agroforests to monoculture plantations in Indonesia. Ecology and Society 15(4):37. http://dx.doi.org/10.5751/ES-03870-150437

Folke, C. 2006. Resilience: the emergence of a perspective for social-ecological systems analyses. Global Environmental Change 16(3):253-267. http://dx.doi.org/10.1016/j.gloenvcha.2006.04.002

Folke, C., S. Carpenter, B. Walker, M. Scheffer, T. Elmqvist, L. Gunderson, and C. S. Holling. 2004. Regime shifts, resilience, and biodiversity in ecosystem management. Annual Review of Ecology, Evolution, and Systematics 35(1):557-581. http://dx.doi. org/10.1146/annurev.ecolsys.35.021103.105711

Folke, C., T. Hahnu, P. Olsson, and J. Norberg. 2005. Adaptive governance of social-ecological systems. Annual Review of Environment and Resources 30(1):441-473. http://dx.doi. org/10.1146/annurev.energy.30.050504.144511

Ghale, Y. 2008. Scoping study on women's leadership in the agriculture sector in Nepal. Women Organizing for Change in Agriculture and NRM (WOCAN), San Francisco, California, USA.

Holling, C. S. 1973. Resilience and stability of ecological systems. Annual Review of Ecology and Systematics 4(1):1-23. http://dx. doi.org/10.1146/annurev.es.04.110173.000245

Klein, R. J. T., R. J. Nicholls, and F. Thomalla. 2003. Resilience to natural hazards: How useful is the concept? Environmental Hazards 5(1):35-45. http://dx.doi.org/10.1016/j.hazards.2004.02.001

Lin, B. B. 2011. Resilience in agriculture through crop diversification: adaptive management for environmental change. BioScience 61(3):183-193. http://dx.doi.org/10.1525/bio.2011.61.3.4

Måren, I. E., K. R. Bhattarai, and R. P. Chaudhary. 2014. Forest ecosystem services and biodiversity in contrasting Himalayan forest management systems. Environmental Conservation 41 (1):73-83. http://dx.doi.org/10.1017/S0376892913000258

Marín, A., S. Gelcich, and J. C. Castilla. 2014. Ecosystem services and abrupt transformations in a coastal wetland social-ecological system: Tubul-Raqui after the 2010 Earthquake in Chile. Ecology and Society 19(1):22. http://dx.doi.org/10.5751/ES-05633-190122

Marschke, M. J., and F. Berkes. 2006. Exploring strategies that build livelihood resilience: a case from Cambodia. Ecology and Society 11(1):42. http://dx.doi.org/10.5751/ES-01730-110142

National Planning Commission (NPC) of the Government of Nepal. 2015. Nepal earthquake 2015: post disaster needs assessment. NPC, Government of Nepal, Kathmandu, Nepal.

O'Connell, D., B. Walker, N. Abel, and N. Grigg. 2015. The resilience, adaptation and transformation assessment framework: from theory to application. CSIRO, Canberra, Australia. [online] URL: http://www.stapgef.org/sites/default/files/documents/CSIROSTAP-Resilience-Adaptation-Transformation-Assessment-FrameworkReport.pdf

Pandit, B. H., K. K. Shrestha, and S. S. Bhattarai. 2014. Sustainable local livelihoods through enhancing agroforestry systems in Nepal. Journal of Forest and Livelihood 12(1):47-63.

Scheffer, M., S. Carpenter, J. A. Foley, C. Folke, and B. Walker. 2001. Catastrophic shifts in ecosystems. Nature 413:591-596. http://dx.doi.org/10.1038/35098000
Scoones, I. 2009. Livelihoods perspectives and rural development. Journal of Peasant Studies 36(1):171-196. http://dx.doi. org/10.1080/03066150902820503

Seidl, R., T. A. Spies, D. L. Peterson, S. L. Stephens, and J. A. Hicke. 2016. Searching for resilience: addressing the impacts of changing disturbance regimes on forest ecosystem services. Journal of Applied Ecology 53(1):120-129. http://dx.doi. org/10.1111/1365-2664.12511

Sen, A. 1985. Commodities and capabilities. Oxford University Press, Oxford, UK.

Tulachan, P. M. 2001. Mountain agriculture in the Hindu KushHimalaya. Mountain Research and Development 21(3):260-267. http://dx.doi.org/10.1659/0276-4741(2001)021[0260:MAITHK]2.0. $\underline{\mathrm{CO} ; 2}$

United Nations Office for Disaster Risk Reduction (UNISDR). 2015. Disaster risk reduction and resilience in the 2030 Agenda for sustainable development. UNISDR, Geneva, Switzerland.

Walker, B. H., L. H. Gunderson, A. P. Kinzig, C. Folke, S. R. Carpenter, and L. Schultz. 2006. A handful of heuristics and some propositions for understanding resilience in social-ecological systems. Ecology and Society 11(1):13. http://dx.doi.org/10.5751/ ES-01530-110113

Walker, T. S., and N. S. Jodha. 1986. How small farm households adapt to risks. Food and Agriculture Organization of the United Nations, Rome, Italy.

White, G. F. 1945. Human adjustment to floods: a geographical approach to the flood problem in the United-States. Research Paper No. 29. Department of Geography-University of Chicago, Chicago, Illinois, USA.

Wisner, B., P. Blaikie, T. Cannon, and I. Davis. 2004. At risk: natural hazards, people's vulnerability and disasters. Second edition. Routledge, London, UK. http://dx.doi.org/10.4324/9780203428764 
Appendix 1. Study site characteristics

Table A.1. Summary of demographic and socio-economic characteristics of study sites collected through survey instrument.

\begin{tabular}{|c|c|c|}
\hline & Sundrawati $(n=39)$ & $\operatorname{Boch}(n=40)$ \\
\hline Respondent, Age & $49(\min 20, \max 80)$ & $51(\min 22, \max 78)$ \\
\hline Household, Size & 4.97 & 5.75 \\
\hline Respondent, Gender & $\begin{array}{l}n=16(41 \%) \text { Female } \\
n=23(59 \%) \text { Male }\end{array}$ & $\begin{array}{l}n=15(37.5 \%) \text { Female } \\
n=25(62.5 \%) \text { Male }\end{array}$ \\
\hline Household, Caste & $\begin{array}{l}5.13 \% \text { Dalit } \\
38.46 \% \text { Brahmin } \\
41.03 \% \text { Thami } \\
15.38 \% \text { Chettri } \\
0.00 \% \text { Thamang }\end{array}$ & $\begin{array}{l}\text { 10.00\% Dali } \\
2.50 \% \text { Brahmin } \\
0.00 \% \text { Thami } \\
45.00 \% \text { Chettri } \\
42.50 \% \text { Thamang }\end{array}$ \\
\hline $\begin{array}{l}\text { Household, primary } \\
\text { livelihoods }\end{array}$ & $\begin{array}{l}82.05 \% \text { Agriculture } \\
10.26 \% \text { Cottage } \\
\text { industry/industry } \\
5.13 \% \text { Casual labor (non-ag) } \\
2.56 \% \text { Service (gov't) }\end{array}$ & $\begin{array}{l}95.00 \% \text { Agriculture } \\
2.50 \% \text { Casual labor } \\
\text { (non-ag) } \\
2.50 \% \text { Other }\end{array}$ \\
\hline $\begin{array}{l}\text { Household, main source of } \\
\text { income }\end{array}$ & $\begin{array}{l}64.0 \% \text { off-farm labor } \\
15.4 \% \text { sells animals } \\
7.7 \% \text { shop/business } \\
5.1 \% \text { remittances } \\
5.1 \% \text { labor }\end{array}$ & $\begin{array}{l}30.0 \% \text { off-farm labor } \\
20.0 \% \text { casual agricultural } \\
\text { labor } \\
20.0 \% \text { sells crops } \\
12.5 \% \text { sells animals } \\
5.0 \% \text { remittances } \\
5.0 \% \text { other } \\
2.5 \% \text { shop/business } \\
2.5 \% \text { government }\end{array}$ \\
\hline
\end{tabular}


Appendix 2. Research methods

Table 2.1. Summary of methodological approaches and research activities.

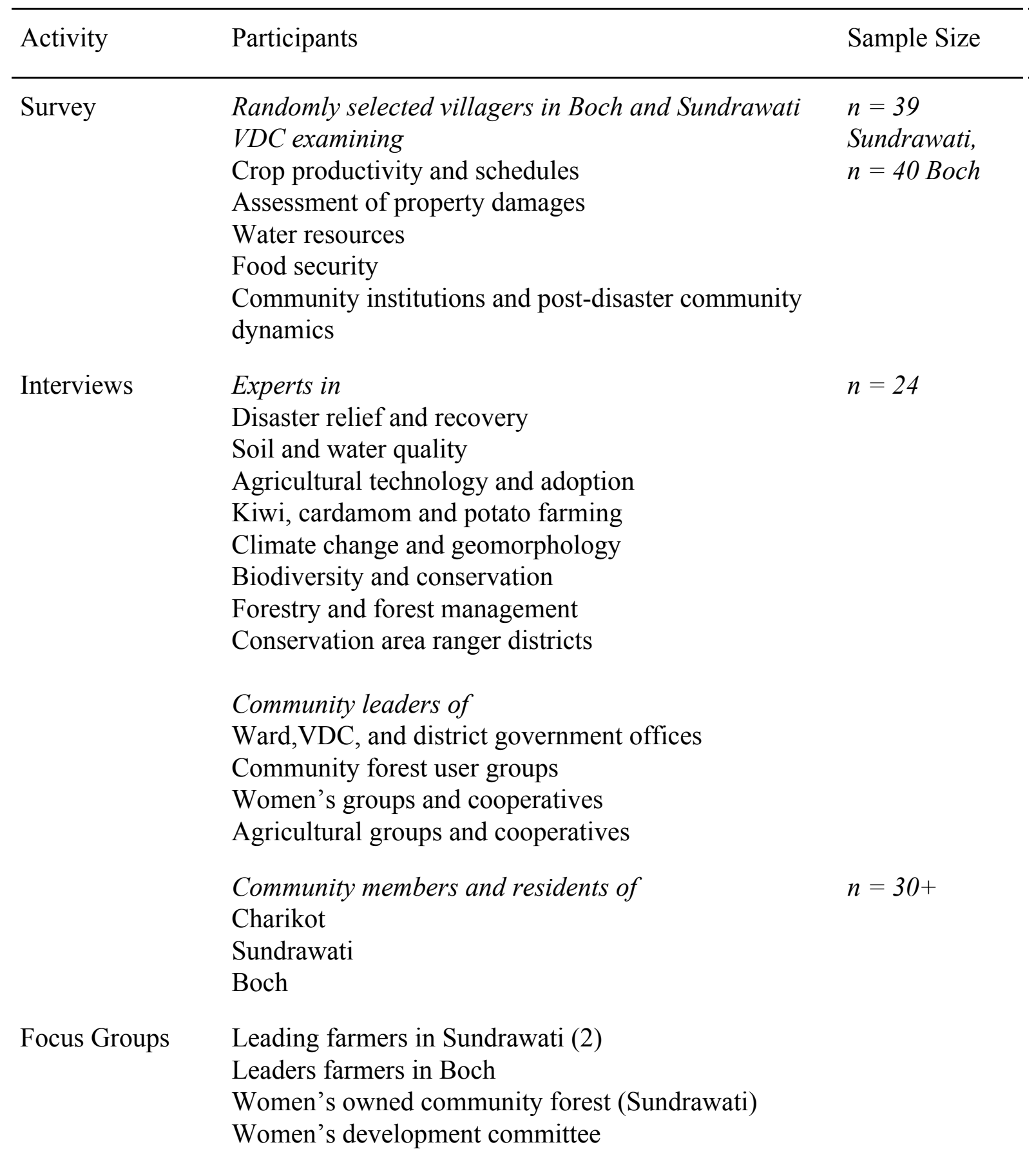


Observational Events include

Village Development Committee meetings

Community Forest Group meetings

Cash crop / agricultural technology workshops

Festivals including a wedding and a funeral 
A3. Survey Questionnaire.

Name of District

Starting time of survey:

Name of VDC

Interview Code

Interview date 2016 - DAY: MONTH:

Personal Information

\begin{tabular}{|c|l|r|}
\hline $\begin{array}{c}\text { Question } \\
\#\end{array}$ & \multicolumn{1}{|c|}{ Question } & Response \\
\hline $\mathbf{0 0 1}$ & Respondent, Age & Male........1 \\
\hline $\mathbf{0 0 2}$ & Respondent, Gender & \\
\hline $\mathbf{0 0 3}$ & How many members in your family? & \\
\hline $\mathbf{0 0 4}$ & What is your occupation? & Open response: \\
& & \\
\hline
\end{tabular}




\section{Part I: Livelihoods and Income Diversity}

Thank you for that information, now we will ask you about your livelihoods and income diversity.

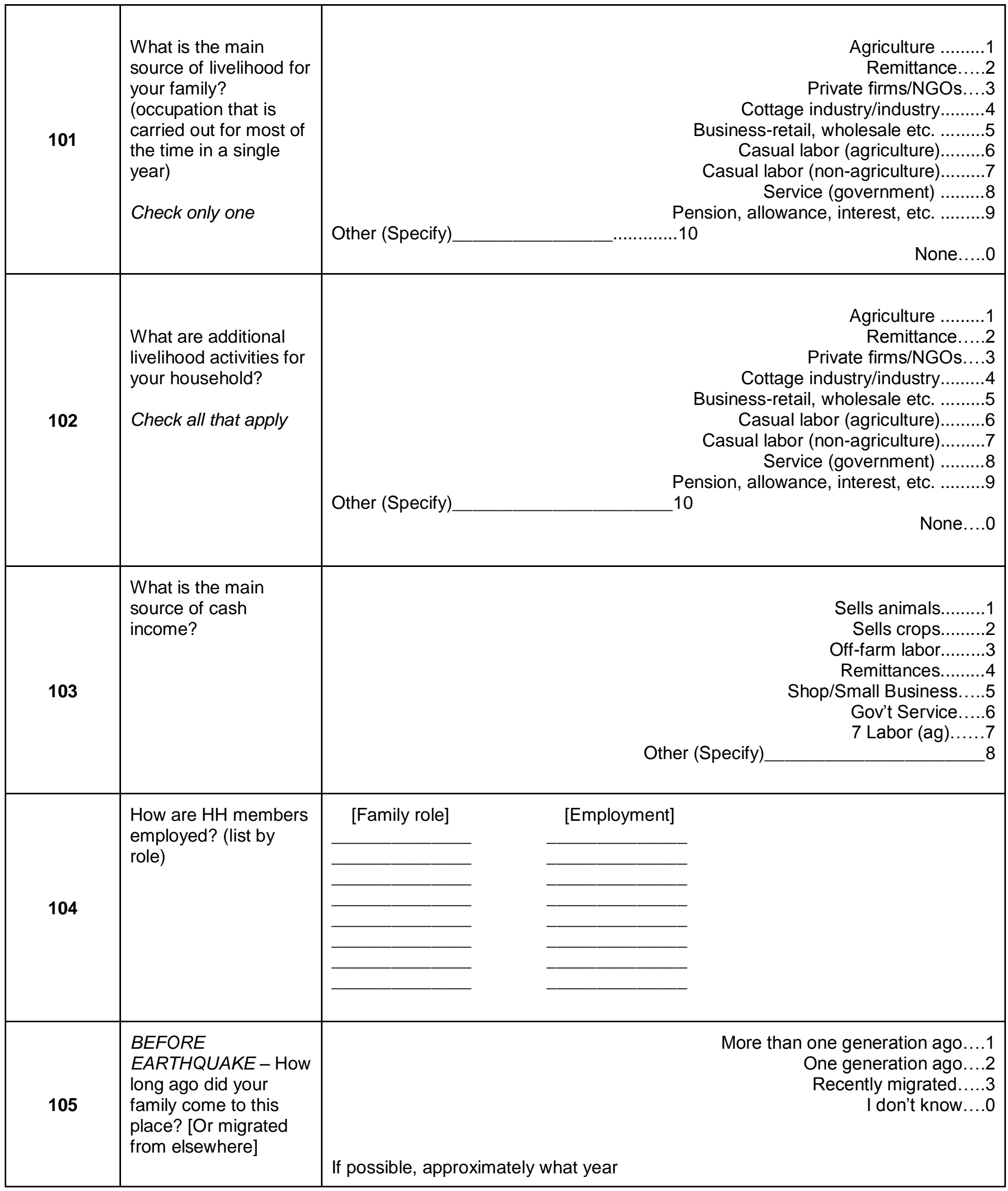




\begin{tabular}{|c|c|c|}
\hline 106 & $\begin{array}{l}\text { BEFORE } \\
\text { EARTHQUAKE - } \\
\text { What was the reason } \\
\text { for your family to } \\
\text { move from their } \\
\text { previous settlement/ } \\
\text { place? (displacement } \\
\text { versus migration) }\end{array}$ & 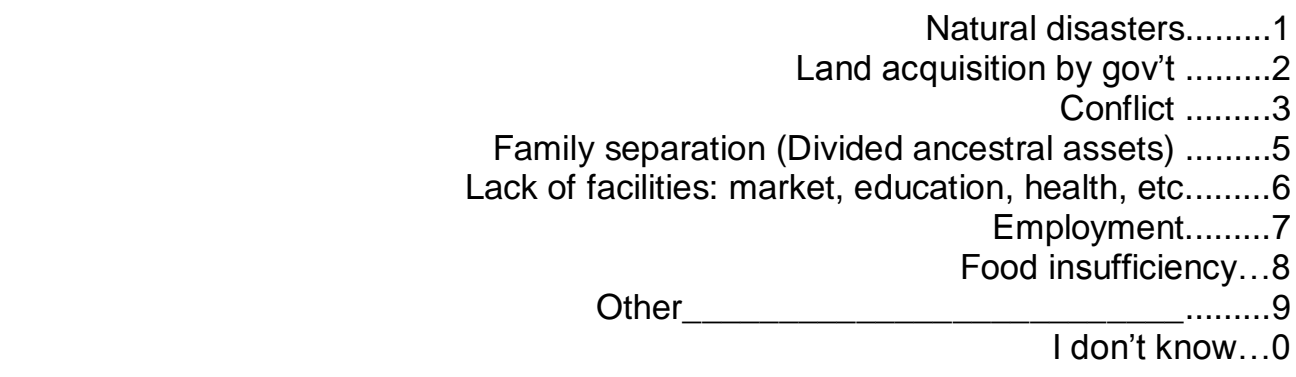 \\
\hline 107 & $\begin{array}{l}\text { Was your house } \\
\text { damaged or destroyed } \\
\text { in the earthquake? }\end{array}$ & $\begin{array}{r}\text { No....0 } \\
\text { Yes...1 } \\
\text { Partially....2 }\end{array}$ \\
\hline 108 & $\begin{array}{l}\text { If your house was } \\
\text { damaged, what type } \\
\text { of structure did you } \\
\text { live in immediately } \\
\text { after the earthquake? }\end{array}$ & 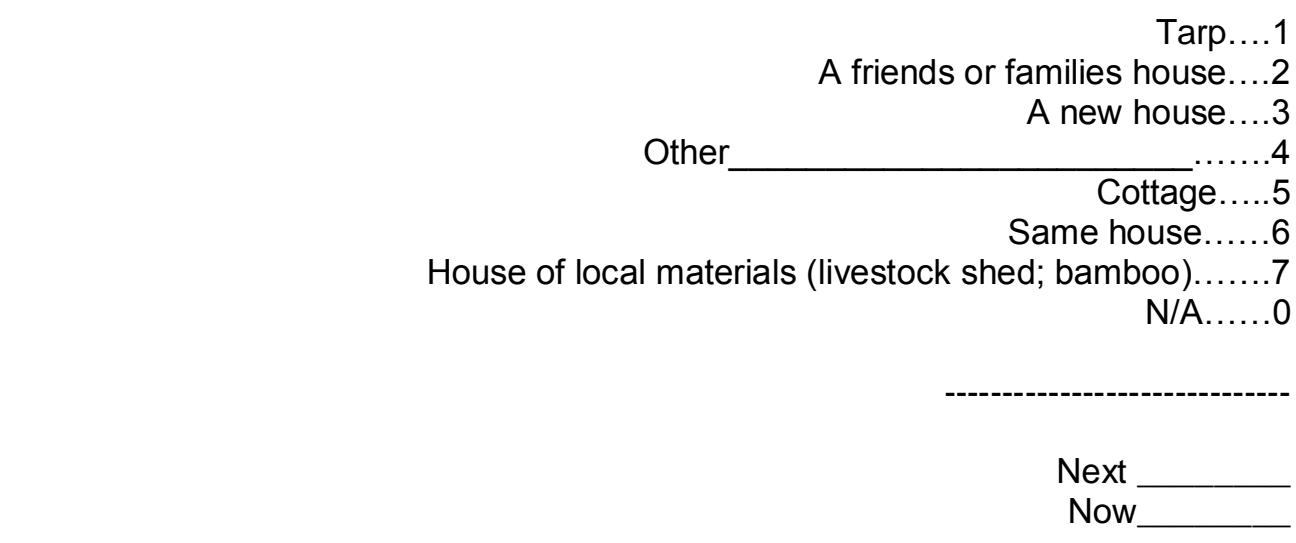 \\
\hline 109 & $\begin{array}{l}\text { Where was this } \\
\text { structures? }\end{array}$ & $\begin{array}{r}\text { Same place.....1 } \\
\text { Own land....2 } \\
\text { Government land.....3 } \\
\text { Other private land.....4 } \\
\ldots . . . . .5\end{array}$ \\
\hline 110 & $\begin{array}{l}\text { If you moved to a new } \\
\text { village, how long? }\end{array}$ & $\begin{array}{r}\text { Yes....1 } \\
\text { No..... }\end{array}$ \\
\hline 111 & $\begin{array}{l}\text { Did you build a new } \\
\text { home? }\end{array}$ & 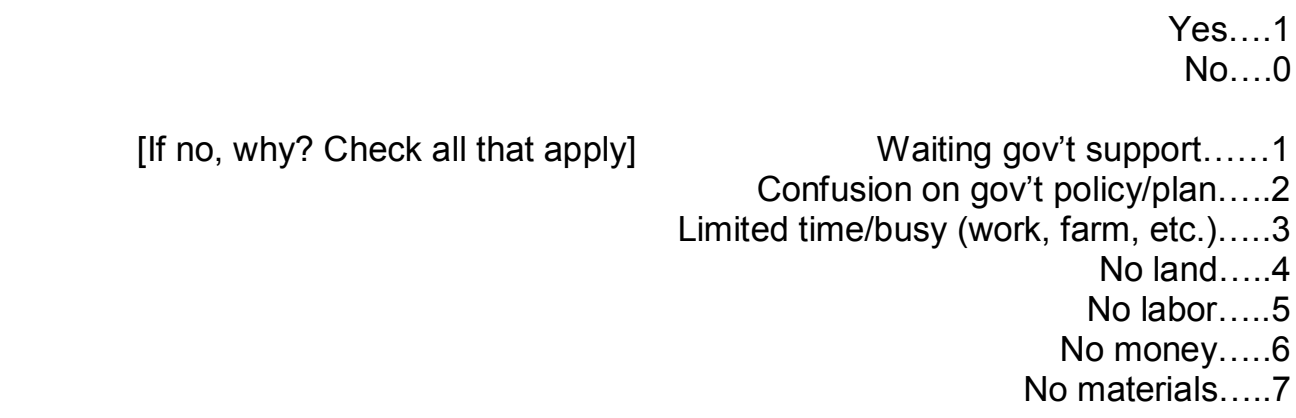 \\
\hline 112 & $\begin{array}{l}\text { How safe is your } \\
\text { current living } \\
\text { situation? }\end{array}$ & $\begin{array}{r}\text { Very safe.....1 } \\
\text { Somewhat safe....2 } \\
\text { Unsafe....3 } \\
\text { I don't know....0 }\end{array}$ \\
\hline
\end{tabular}




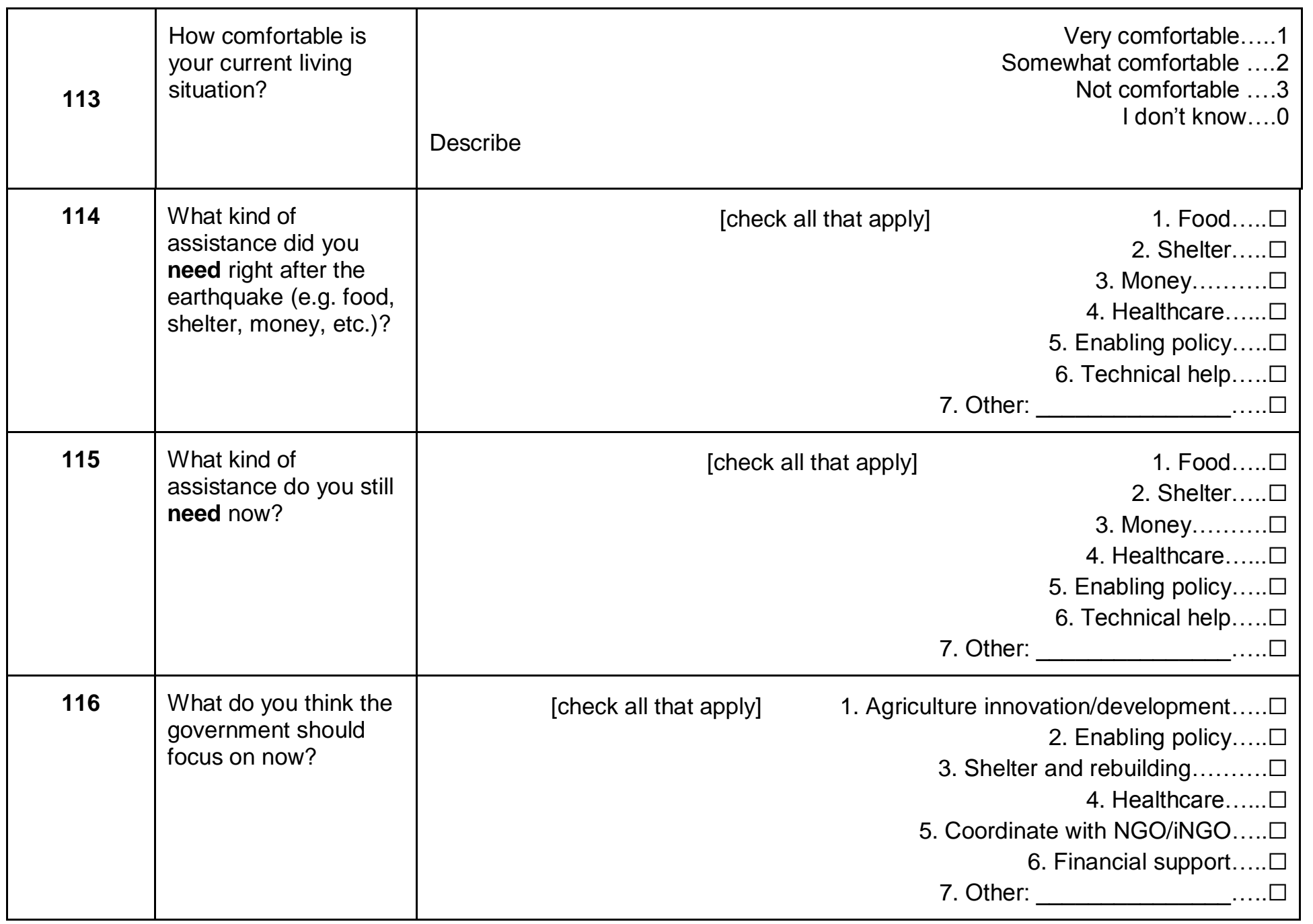


Part II: Property and Crop Use

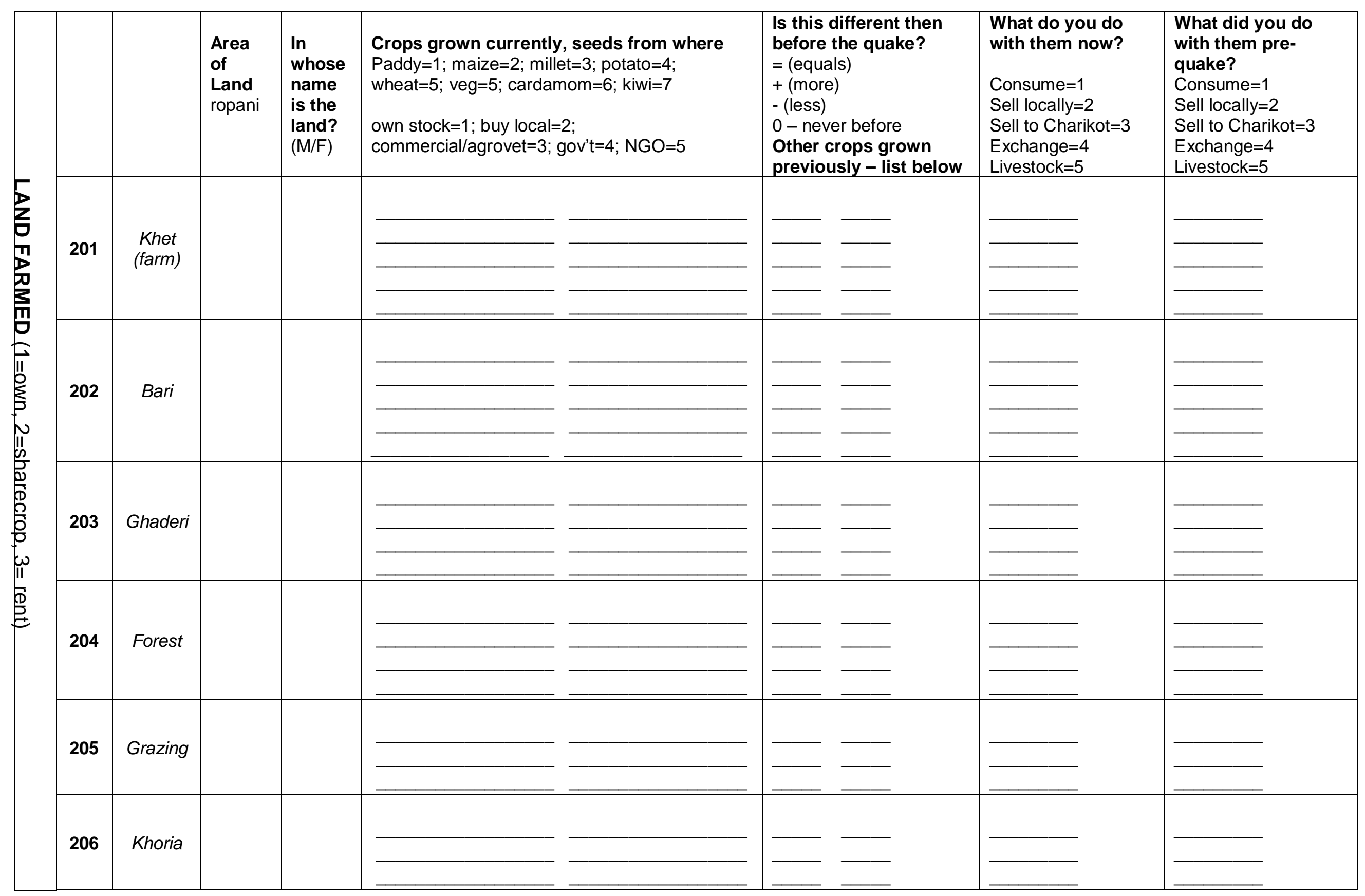


Part III: Farm structures: livestock, seeds and irrigation

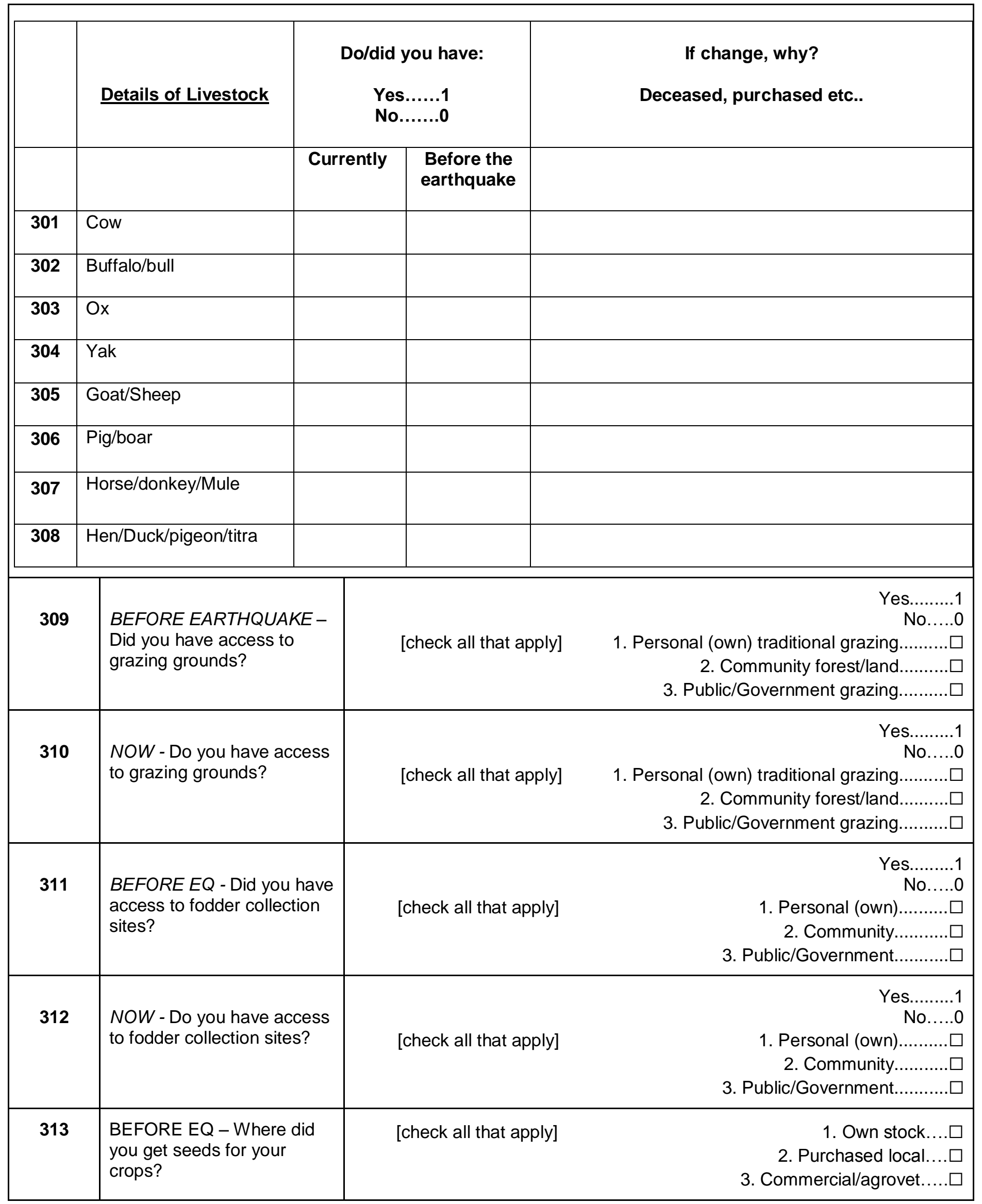




\begin{tabular}{|c|c|c|}
\hline & & $\begin{array}{r}\text { 4. Provided by gov/ngo...... } \\
\text { 5. Don't know.... }\end{array}$ \\
\hline 314 & $\begin{array}{l}\text { NOW - Where did you get } \\
\text { seeds for your crops? }\end{array}$ & $\begin{array}{r}\text { 1. Own stock.... } \\
\text { 2. Purchased local.... } \\
\text { 3. Commercial/agrovet..... } \\
\text { 4. Provided by gov/ngo..... } \\
\text { 5. Don't know.... }\end{array}$ \\
\hline 315 & $\begin{array}{l}\text { How were your seed stocks } \\
\text { impacted by earthquake? }\end{array}$ & $\begin{array}{r}\text { Complete destroyed.....1 } \\
\text { Partially destroyed.....2 } \\
\text { Not destroyed.....3 }\end{array}$ \\
\hline \multirow[t]{2}{*}{316} & \multirow[t]{2}{*}{$\begin{array}{l}\text { What types of fertilizers do } \\
\text { you use? }\end{array}$} & $\begin{array}{r}\text { Organic (compost) } \ldots . .1 \\
\text { Non-Organic/Chemical (e.g.Urea).....2 } \\
\text { None.....0 }\end{array}$ \\
\hline & & $\begin{array}{r}\text { If on subsistence crops.....3 } \\
\text { If on market crops (to sell)....4 } \\
\text { If both.....5 }\end{array}$ \\
\hline 317 & $\begin{array}{l}\text { Is this different then before } \\
\text { the earthquake? }\end{array}$ & $\begin{array}{r}\text { Yes.....1 } \\
\text { No....0 }\end{array}$ \\
\hline \multirow[t]{2}{*}{318} & \multirow[t]{2}{*}{$\begin{array}{l}\text { What types of pesticides do } \\
\text { you use? }\end{array}$} & $\begin{array}{r}\text { Organic (compost) } \ldots . .1 \\
\text { Non-organic/chemical (e.g.urea, DPA, potass) } \ldots . .2 \\
\text { None..... }\end{array}$ \\
\hline & & $\begin{array}{r}\text { If on subsistence crops.....3 } \\
\text { If on market crops (to sell)....4 } \\
\text { If both.....5 }\end{array}$ \\
\hline 319 & $\begin{array}{l}\text { Is this different then before } \\
\text { the earthquake? }\end{array}$ & $\begin{array}{r}\text { Yes.....1 } \\
\text { No.....0 }\end{array}$ \\
\hline 320 & $\begin{array}{l}\text { BEFORE EQ - Where did } \\
\text { your irrigation water come } \\
\text { from? }\end{array}$ & $\begin{array}{r}\text { Local river......1 } \\
\text { Local spring....2 } \\
\text { Local pond.....3 } \\
\text { Rainfed......4 } \\
\ldots \ldots . .5 \\
\text { I don't know..... }\end{array}$ \\
\hline 321 & $\begin{array}{l}\text { NOW - Where does your } \\
\text { irrigation water come from } \\
\text { now? }\end{array}$ & $\begin{array}{r}\text { Local river......1 } \\
\text { Local spring....2 } \\
\text { Local pond.....3 } \\
\text { Rainfed......4 } \\
\ldots \ldots . .5 \\
\text { I don't know..... }\end{array}$ \\
\hline 322 & If 320 and 321 are different & \\
\hline 323 & $\begin{array}{l}\text { BEFORE THE EQ - How } \\
\text { did you irrigate your fields? }\end{array}$ & $\begin{array}{l}\text { Personal traditional canal.........1 } \\
\text { Collective traditional canal......... } \\
\text { Improved/government canal...3 } \\
\text { Temporary (rain fed) canal........4 } \\
\ldots . . . . . . .5 \\
\text { None........ }\end{array}$ \\
\hline 324 & $\begin{array}{l}\text { NOW - What type of } \\
\text { irrigation do you use? }\end{array}$ & $\begin{array}{l}\text { Personal traditional canal.........1 } \\
\text { Collective traditional canal.........2 }\end{array}$ \\
\hline
\end{tabular}




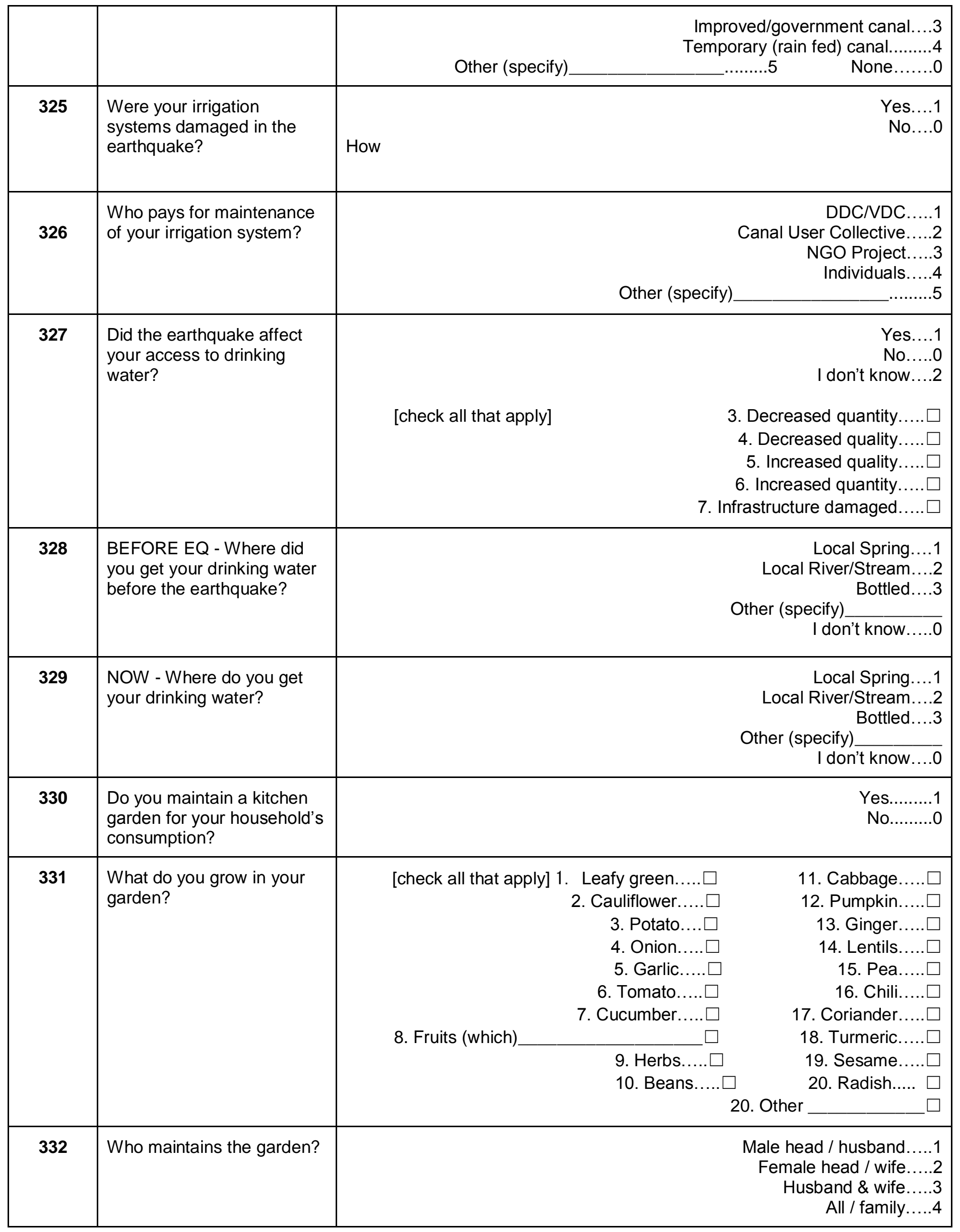




\begin{tabular}{|c|c|c|c|}
\hline & & & $\begin{array}{r}\text { Women in family.....5 } \\
\text { Child / children.....6 } \\
. . . . . . .7\end{array}$ \\
\hline 333 & $\begin{array}{l}\text { How important is the garden } \\
\text { for feeding your family? }\end{array}$ & & $\begin{array}{r}\text { Very important.....1 } \\
\text { Somewhat important....2 } \\
\text { Not important..... } \\
\text { I don't know..... }\end{array}$ \\
\hline 334 & $\begin{array}{l}\text { Has reliance on home } \\
\text { grown food increased or } \\
\text { decreased over last } 10 \\
\text { years? }\end{array}$ & & $\begin{array}{r}\text { Increased........1 } \\
\text { Decreased........2 } \\
\text { No change......... }\end{array}$ \\
\hline 335 & $\begin{array}{l}\text { Has reliance on home } \\
\text { grown food increased or } \\
\text { decreased in the year since } \\
\text { the earthquake? }\end{array}$ & & $\begin{array}{r}\text { Increased..........1 } \\
\text { Decreased........2 } \\
\text { No change........0 }\end{array}$ \\
\hline 336 & $\begin{array}{l}\text { Does the family buy other } \\
\text { foods (other than } \\
\text { homegrown)? }\end{array}$ & & 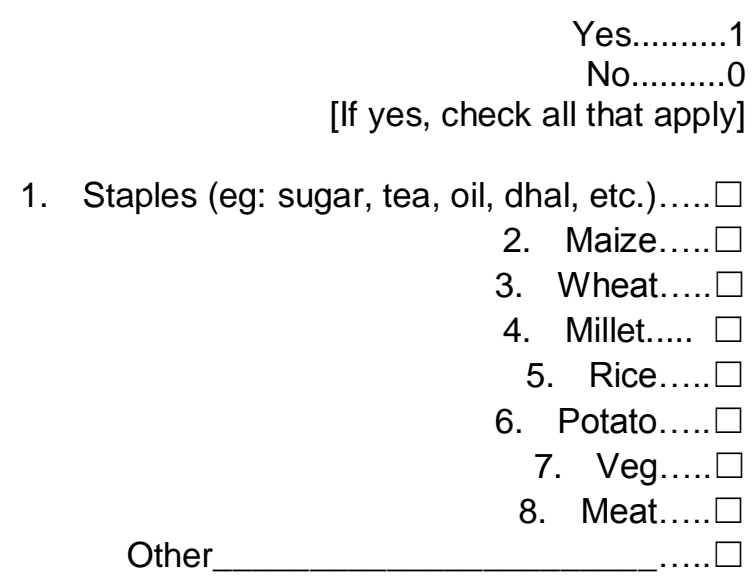 \\
\hline 337 & $\begin{array}{l}\text { Was your food storage } \\
\text { system impacted by the } \\
\text { earthquake? }\end{array}$ & 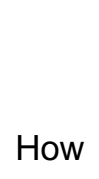 & $\begin{array}{r}\text { Yes....1 } \\
\text { No....0 } \\
\text { Don't know...2 }\end{array}$ \\
\hline 338 & $\begin{array}{l}\text { Immediately following the } \\
\text { earthquake (during initial } \\
\text { rescue and relief period), } \\
\text { how did you get food? }\end{array}$ & & $\begin{array}{r}\text { [Check all that apply] } \\
\text { 1. Own food..... } \\
\text { 2. Communal food.... } \\
\text { 3. Relief food..... } \\
\text { 4. Buy at shop..... } \\
\text { 5. Other }\end{array}$ \\
\hline 339 & $\begin{array}{l}\text { BEFORE EQ - Did you } \\
\text { exchange labor to assist } \\
\text { with farming activities? }\end{array}$ & & $\begin{array}{r}\text { Yes.....1 } \\
\text { No..... } \\
\\
\text { [check all that apply] } \\
\text { 2. Exchange labor..... } \\
\text { 3. Hired labor..... }\end{array}$ \\
\hline
\end{tabular}




\begin{tabular}{|c|c|c|c|}
\hline 340 & $\begin{array}{l}\text { NOW - Do you hire labor to } \\
\text { assist with farming } \\
\text { activities? }\end{array}$ & & $\begin{array}{r}\text { Yes...1 } \\
\text { No.... } \\
\text { [check all that apply] } \\
\text { 2. Exchange labor..... } \\
\text { 3. Hired labor..... }\end{array}$ \\
\hline 341 & $\begin{array}{l}\text { Have you changed any } \\
\text { farming practices due to the } \\
\text { earthquake? }\end{array}$ & & $\begin{array}{r}\text { Yes....1 } \\
\text { No...... } \\
\text { 2. New crops..... } \square \\
\text { 3. New seed source..... } \\
\text { 4. New animals..... } \\
\text { 5. New farm buildings..... } \\
\text { 6. New terraces or beds..... } \\
\text { 7. New infrastructure..... } \\
\text { 8. Left Fallow..... } \\
\end{array}$ \\
\hline 342 & $\begin{array}{l}\text { Would you implement } \\
\text { anything different now after } \\
\text { the earthquake? }\end{array}$ & What & $\begin{array}{l}\text { Yes...1 } \\
\text { No.... }\end{array}$ \\
\hline 343 & $\begin{array}{l}\text { Immediately following the } \\
\text { earthquake, how did you } \\
\text { use your field? }\end{array}$ & & $\begin{array}{r}\text { 1. Fallow..... } \square \\
\text { 2. Planted, but less..... } \\
\text { 3. Planted, but same...... } \\
\text { 1. Fallow..... } \square \\
\text { 2. Planted, but less..... } \\
\text { 3. Planted, but same ...... } \\
\text { 4. Build structure (house/shed)..... }\end{array}$ \\
\hline 344 & $\begin{array}{l}\text { As a farmer, what gov't } \\
\text { policies and programs have } \\
\text { you participated in or } \\
\text { benefited from? }\end{array}$ & & $\begin{array}{r}\text { Capacity building.....1 } \\
\text { Materials..... } \\
\text { Technical assistance, farming practices..... } \\
\text { Technical assistance, water....4 } \\
\text { Technical assistance, seeds..... } \\
\text { Subsidies.......6 } \\
\text { Grants..... } \\
\text { Loans.....8 } \\
\text { Other }\end{array}$ \\
\hline
\end{tabular}

\section{Part IV: Institutions, Community Property and Natural Resource Management}

And now we would like to think about your community more broadly.

\begin{tabular}{|c|l|r|}
\hline Question \# & \multicolumn{1}{|c|}{ Question } & \multicolumn{1}{|c|}{ Response } \\
\hline $\mathbf{4 0 1}$ & $\begin{array}{l}\text { Are you or someone in your family a } \\
\text { member of community networks on your } \\
\text { village? }\end{array}$ & Yes .......1 \\
No......... \\
[Check all that apply]
\end{tabular}




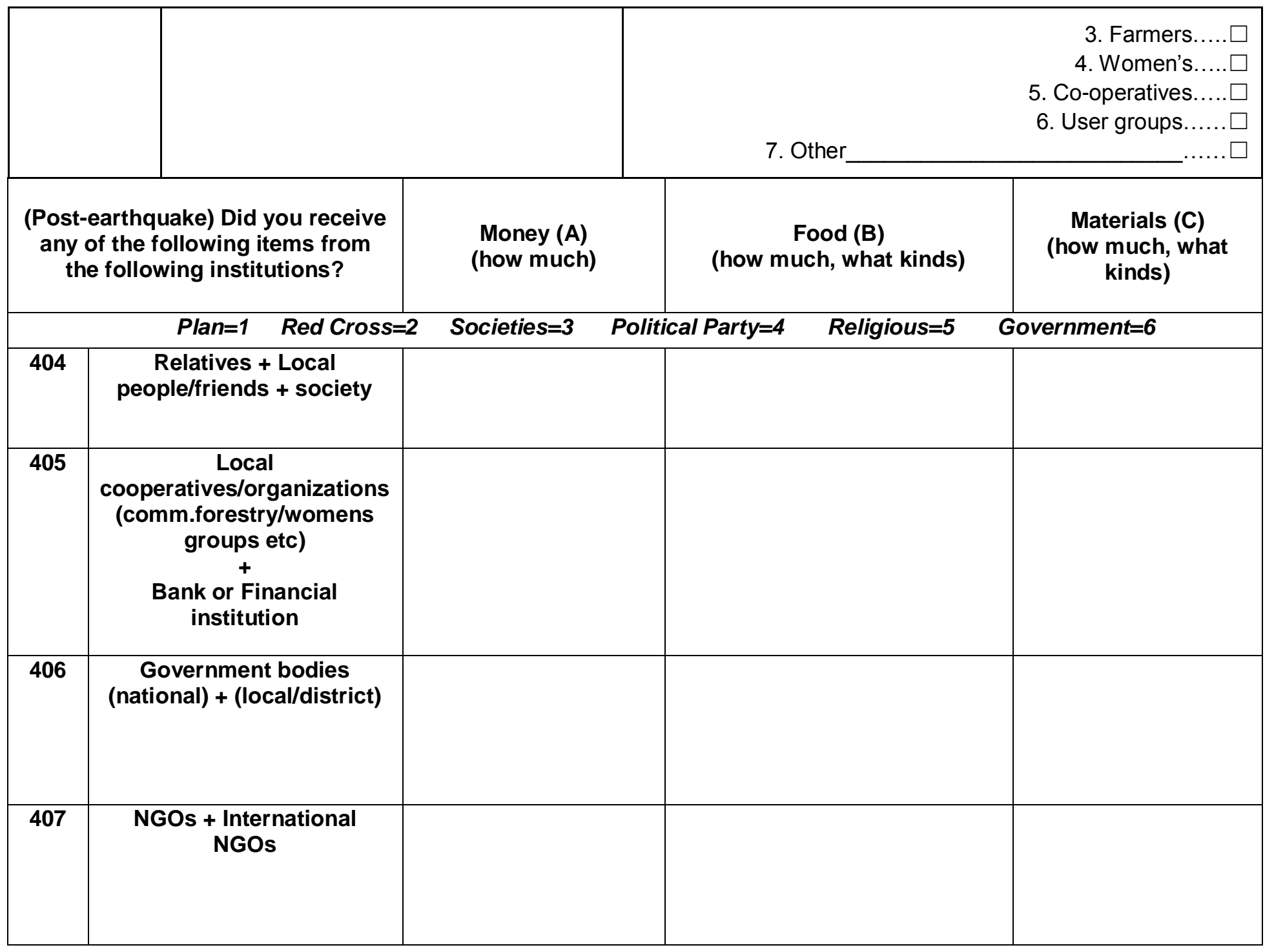

\begin{tabular}{|c|c|c|c|}
\hline 412 & What types of aid were most useful? & Open ended & \\
\hline 413 & $\begin{array}{l}\text { Do you feel the government met your } \\
\text { expectations regarding support during } \\
\text { rescue and relief? }\end{array}$ & Open ended & $\begin{array}{r}\text { Very highly met.....1 } \\
\text { Somewhat met....2 } \\
\text { Not at all met....3 } \\
\text { I don't know.... }\end{array}$ \\
\hline 414 & $\begin{array}{l}\text { Do you feel the government is } \\
\text { meeting your expectations during } \\
\text { reconstruction? }\end{array}$ & Open ended & $\begin{array}{r}\text { Very highly met.....1 } \\
\text { Somewhat met....2 } \\
\text { Not at all met....3 } \\
\text { I don't know.... }\end{array}$ \\
\hline
\end{tabular}




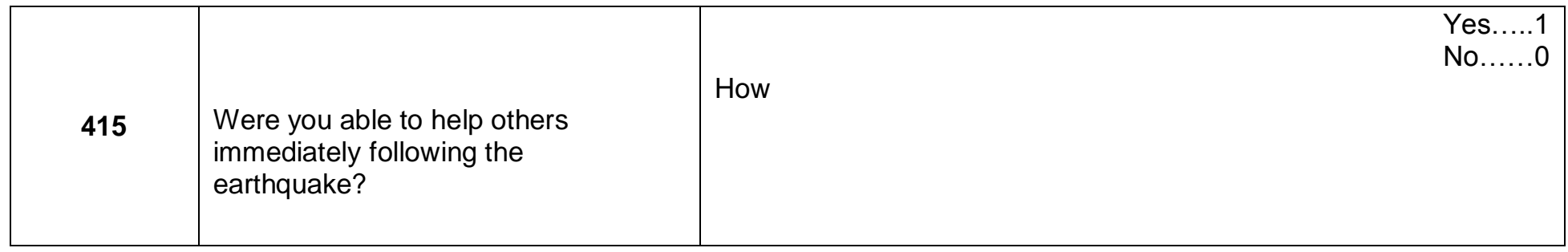


Part V: Resilience Assessment

We would now like to ask you to report on a series of short statements that describe how different elements of your life have changed from before the earthquake to now...

The productivity of my farm in terms of food

production (quantity for consumption)

502 The productivity of my farm in terms of cash crop production (for selling)

503 The quality of crops that I produce

504 The diversity of the crops that I produce

505 The use of chemical pesticides in my farm

506 The use of machines on my farm

507 The use of chemical fertilizers in my farm

508 The storage system of my seeds for planting

509 Erosion issues around my farm

510 My access to drinking water

511 My access to irrigation water

512 My irrigation system

513 The status of my livestock herds

514 My access to grazing lands

515 My access to forest resources

516 My access to a safe housing structure

517 My access to a comfortable house structure

518 My farm structures

519

My income from local off-farm occupations

(crafts, labor)

520 The amount of money I receive from remittances

521 My family's access to local schools

522 My access clean toilets
Immediately following EQ (0-6 months)

\begin{tabular}{|c|c|c|c|c|}
\hline Impr & Incr & Decl & Decr & $\begin{array}{c}\text { Stayed } \\
\text { the } \\
\text { same }\end{array}$ \\
\hline
\end{tabular}

6 months to 1 year after EQ (until now)

\begin{tabular}{|c|c|c|c|c|}
\hline Impr & Incr & Decl & Decr & \begin{tabular}{|l|} 
Stayed \\
the \\
same
\end{tabular} \\
\hline & & & & \\
\hline & & & & \\
\hline & & & & \\
\hline & & & & \\
\hline & & & & \\
\hline & & & & \\
\hline & & & & \\
\hline & & & & \\
\hline & & & & \\
\hline & & & & \\
\hline & & & & \\
\hline & & & & \\
\hline & & & & \\
\hline & & & & \\
\hline & & & & \\
\hline & & & & \\
\hline & & & & \\
\hline & & & & \\
\hline & & & & \\
\hline & & & & \\
\hline & & & & \\
\hline & & & & \\
\hline
\end{tabular}




\begin{tabular}{|c|c|c|c|c|c|c|c|c|c|c|c|}
\hline & & Impr & Incr & Decl & Decr & $\begin{array}{l}\text { Stayed } \\
\text { the } \\
\text { same }\end{array}$ & Impr & Incr & Decl & Decr & $\begin{array}{l}\text { Stayed } \\
\text { the } \\
\text { same }\end{array}$ \\
\hline 523 & My access to water for washing/cleaning & & & & & & & & & & \\
\hline 524 & My family's access to local health facilities & & & & & & & & & & \\
\hline 525 & $\begin{array}{l}\text { The number of months I can provide food for my } \\
\text { family from the farm }\end{array}$ & & & & & & & & & & \\
\hline 526 & $\begin{array}{l}\text { The number of days I felt my family did not have } \\
\text { enough to eat }\end{array}$ & & & & & & & & & & \\
\hline 527 & My fear of earthquakes or natural disasters & & & & & & & & & & \\
\hline 528 & $\begin{array}{l}\text { My ability to cope with future } \\
\text { earthquakes/landslides }\end{array}$ & & & & & & & & & & \\
\hline 529 & My participation in festival events & & & & & & & & & & \\
\hline 530 & My participation in local community groups & & & & & & & & & & \\
\hline 531 & $\begin{array}{l}\text { My ability to visit with non-local friends and } \\
\text { neighbors }\end{array}$ & & & & & & & & & & \\
\hline 532 & My capacity to help with rebuilding efforts & & & & & & & & & & \\
\hline 533 & My reliance on INGO/NGO aid & & & & & & & & & & \\
\hline 534 & My reliance on local institutions & & & & & & & & & & \\
\hline 535 & The use of livestock on my farm & & & & & & & & & & \\
\hline 536 & The physical health of me and my family & & & & & & & & & & \\
\hline 537 & $\begin{array}{l}\text { In terms of earthquake impact, how do you f } \\
\text { your family fared compared to other families } \\
\text { your communit }\end{array}$ & & Describe & & & & & & & $\begin{array}{c}\text { Some } \\
\text { Some }\end{array}$ & $\begin{array}{l}\text { better...1 } \\
\text { better....2 } \\
\text { qqual..... } \\
\text { worse ....4 } \\
\text { tworse...5 } \\
\text { know..... }\end{array}$ \\
\hline 538 & $\begin{array}{r}\text { In terms of earthquake reconstruction, how } \\
\text { you feel your family fared compared to ot } \\
\text { families in your communit }\end{array}$ & & Describe & & & & & & & $\begin{array}{l}\text { Some } \\
\text { Some }\end{array}$ & $\begin{array}{l}\text { better...1 } \\
\text { better....2 } \\
\text { qqual.....3 } \\
\text { worse } \ldots . .4 \\
\text { tworse... } \\
t \text { know.... }\end{array}$ \\
\hline
\end{tabular}


Appendix 4. Earthquake impacts to social and ecological systems

Figure A4.1a. \& 4.1b. Box plots showing the distribution of adaptation and recovery scores at time "1 Year After EQ" between (a) castes and (b) the presence or absence of cash crops in farming systems. The variability within these groups vary, and highlights the range of resilience perceptions, even if the median is similar across groups. The box contains the middle $50 \%$ of the data, the upper edge of the box indicates 75 th percentile of the data and the lower edge indicated 25th percentile. The black line inside the box is the median and the ends of the horizontal lines, the "whiskers", represent minimum and maximum values. Plots showing analysis of community and household level variables are available upon request.

a.

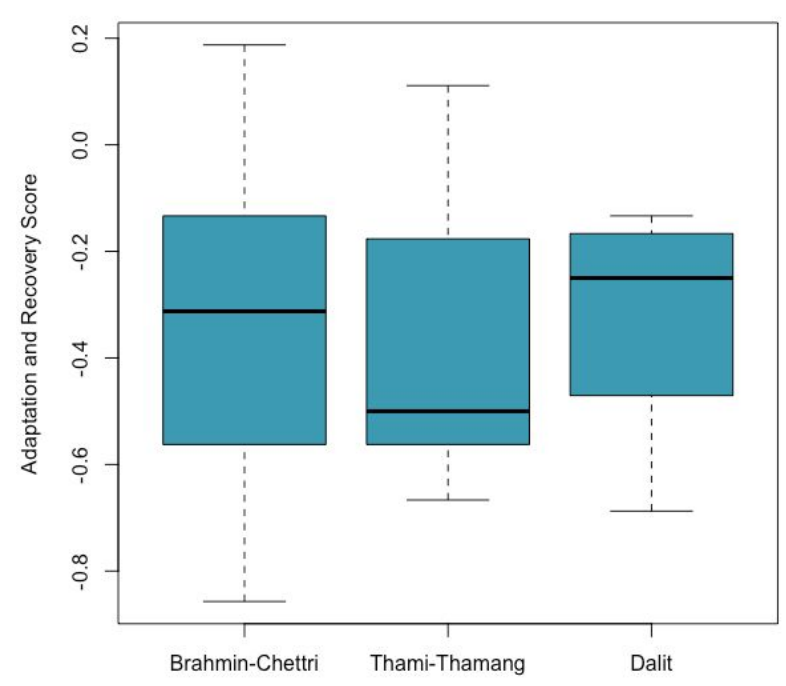

b.

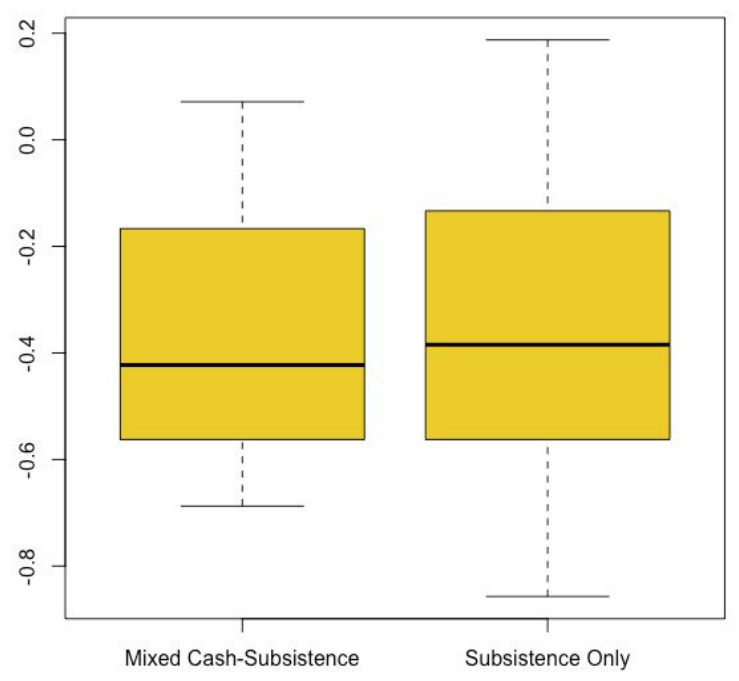


Figure A4.2. Plot of 'self-reliance' adaptation and recovery assessment scores at "0-6 Months After EQ" and "1 Year After EQ" by caste.

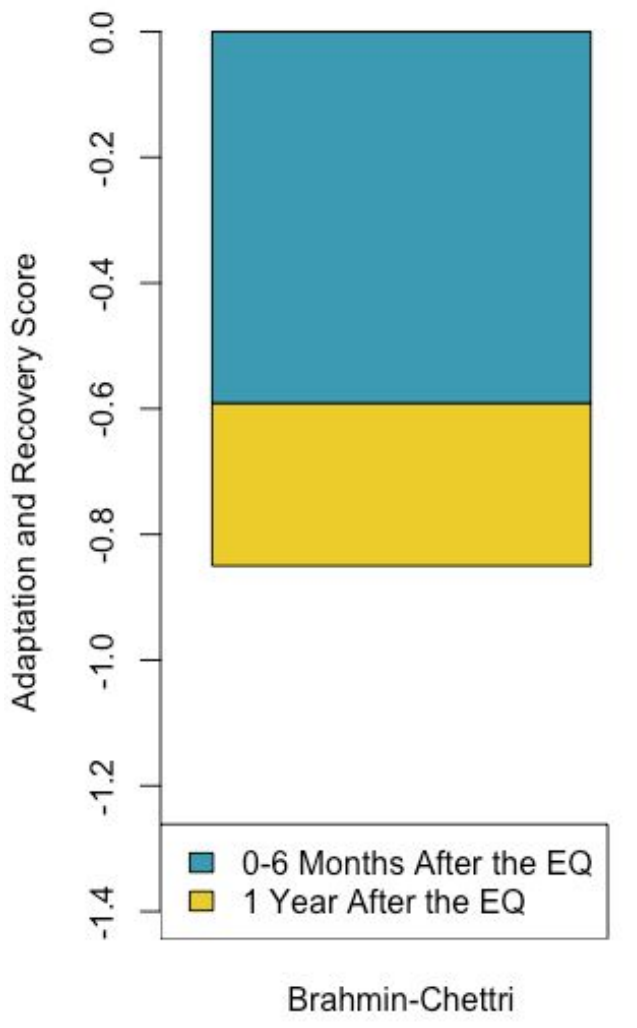

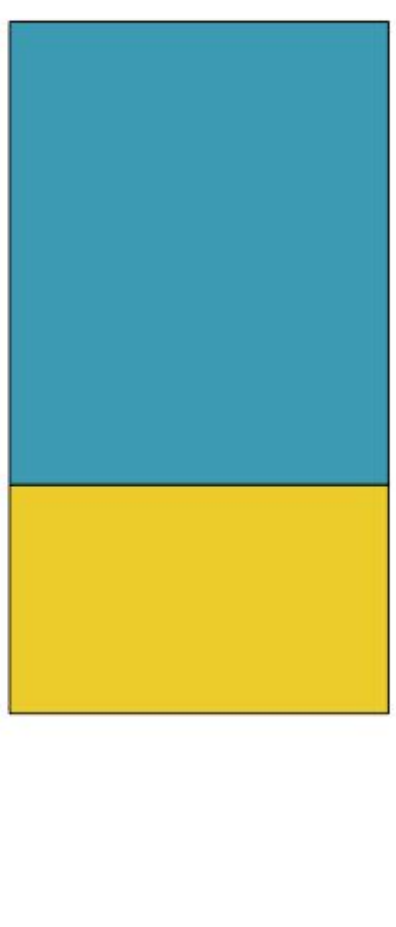

Thami-Thamang

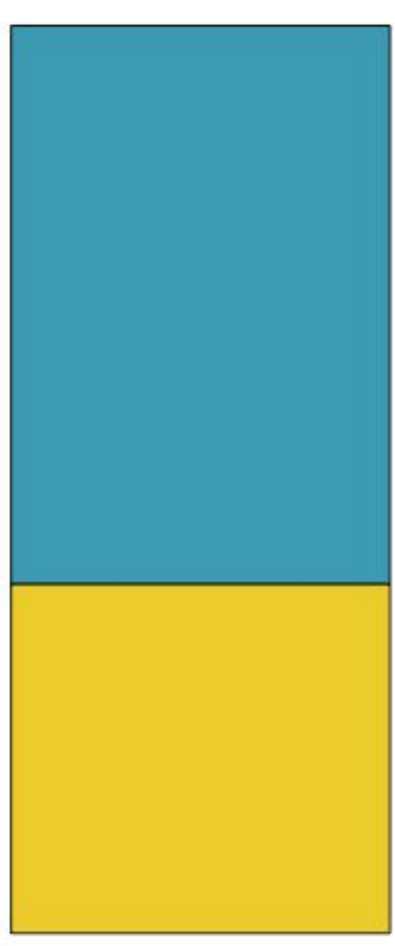

Dalit 